\title{
Os remeiros do São Francisco na literatura
}

\author{
Zanoni $\mathrm{N}$ eves \\ M estre em A ntropologia Social - U nicamp \\ Coordenador do N úcleo de E studos da Cultura Mineira
}

\begin{abstract}
RE SUMO : Ao longo de dois séculos, os remeiros contribuíram para a formação e o desenvolvimento do sistema econômico regional no Médio São Francisco. Por sua importância social, foram mencionados por viajantes e técnicos em seus relatos sobre a região. Mas o trabalho, as crenças, a posição social dos remeiros podem ser conhecidos também por intermédio da literatura de ficção: estão presentes no conto e no romance regionalistas. Assim, utilizamos essas fontes para dar continuidade ao nosso trabalho de interpretação iniciado no livro $\mathrm{N}$ avegantes da integração: os remeiros do rio São Francisoo, no qual utilizamos sobretudo o recurso metodológico de entrevistas. No presente artigo, os relatos e a literatura de ficção são confrontados com as informações do livro acima mencionado.
\end{abstract}

PALAVRAS-CHAVE: remeiros; barcas; rio São Francisco; sistema econômico regional; ideologia; estigma; trabalho; conto; romance.

\section{Introdução}

Em nosso livro publicado sobre os remeiros do rio São Francisco (Neves, 1998), abordamos inicialmente a história da navegação sem descurar da pecuária e das missões religiosas. Procuramos demonstrar a existência do todo sem perder de vista as "partes" que o constituíram. Neste particu- 
lar, os núcleos urbanos ribeirinhos, que gradativamente se desenvolviam, foram os lugares privilegiados da integração regional e inter-regional desde 0 período colonial. Na segunda parte, interpretamos o trabalho dos remeiros com ênfase nas relações entre os grupos de trabalhadores nas barcas e seus patrões sem perder de vista a faina diária nas viagens pelo São Francisco. Na terceira, descrevemos as relações entre os remeiros e as camadas sociais das cidades ribeirinhas com o intuito de conhecer a posição social daqueles trabalhadores, interpretando a discriminação social e 0 estigma a que estavam submetidos. As histórias de vida transcritas na quarta parte do livro ajudaram-nos a aprofundar o conhecimento da vida social dos remeiros e de sua cultura. Por fim, abordamos o sistema de crenças ribeirinho, do qual participavam aqueles navegantes, com destaque para o catolicismo popular, os mitos fluviais e rurais e a magia. Como recurso metodológico, utilizamos entrevistas concedidas por habitantes das cidades ribeirinhas incluindo evidentemente 0 discurso dos ex-remeiros e de seus patrões. Mas consultamos também os relatos de viagem e a literatura de ficção como fontes subsidiárias.

No presente artigo, concentramos nossa pesquisa na literatura de fição, ou seja, no conto e no romance regionalista, dos quais os remeiros são personagens. Mas recorremos também à literatura produzida por cronistas, ou seja, viajantes, técnicos e missionários que estiveram no Médio São Francisco, sem perder de vista as entrevistas anteriormente mencionadas. Podemos afirmar que este texto complementa o trabalho de interpretação elaborado no livro acima referido, o qual citamos na bibliografia.

Primeiramente, desejamos investigar as condições em que foi realizado o trabalho dos remeiros - os tripulantes das barcas de figura. Ressaltamos, entretanto, que não se pode perder de vista o trabalho e a ação de outras classes sociais: no meio rural, vaqueiros e lavradores; nos nú- 
cleos urbanos, ferreiros, seleiros, carpinteiros, marceneiros etc.; no setor de transportes, tropeiros, carreiros, carroceiros, balseiros, paqueteiros etc. Enfim, é nosso propósito demonstrar o papel dos remeiros na formação e no desenvolvimento econômico do Brasil-nação, estando ciente da existência de atividades profissionais que se inter-relacionavam.

0 leitor pode até se surpreender com o duro regime de trabalho nas barcas, ainda que sejamos pródigos na citação de entrevistas e autores contemporâneos sobre os remeiros. Nesse particular, éimportante lembrar o que afirma o antropólogo Claude Lévi-Strauss:

Não obstante, todo etnólogo que tenha trabalhado nesse campo sabe que essas possibilidades (do corpo do homem) são surpreendentemente variáveis segundo os grupos. Os limiares de excitabilidade, os limites de resistência são diferentes em cada cultura. (1974, p. 4-5)

E em seguida o referido autor acrescenta: "o homem, sempre e em toda parte, soube fazer do seu corpo um produto de suas técnicas e de suas representações" (p. 5). Em face da faina diária a que se submetiam, os remeiros desenvolveram uma grande resistência física, adaptando seu corpo ao processo de trabalho nas barcas. Mas, por outro lado, pretendemos demonstrar como esse trabalho e sua marca no corpo dos remeiros contribuíram para a formação do estigma que os identificavam nas cidades ribeirinhas.

Para conhecermos a posição social dos remeiros naquela região, devemos interpretá-la em dois níveis que se nos apresentam inter-relacionados: no nível das relacoues sociais de trabalho e no das representaçóes. Nesse particular, vejamos o conceito de ideologia que se presta ao conhecimento das representações sociais vigentes nos povoados, vilas e cidades ribeirinhas: 
Tanto a teoria do interesse como a teoria da tensão vão diretamente da análise das fontes à análise das conseqüências, sem nunca examinarem seriamente as ideologias como sistemas de símbolos interatuantes, como padrões de significados entrelaçados. (1978, p. 177-78)

O conceito de estigma nos permite conhecer a identidade deteriorada (G offman, 1982) que caracterizava a vida social dos remeiros. A professora Alba Zaluar também contribui com um texto fundamental para compreendermos a natureza das relações sociais que os referidos navegantes estabeleciam nas cidades ribeirinhas: "Uma das expressões da dominação é a construção da identidade do dominado pelo dominador. E uma das técnicas repressivas é a estigmatização de quem se quer reprimir" (Zaluar, 1985, p. 168). A nosso ver, as noções de discriminação e a desqualificação social nos ajudam também a compreender a formação de estigmas contra grupos sociais, etnias e indivíduos.

Com este ensaio, tencionamos demonstrar também a função exercida pelas barcas no Médio São Francisco com ênfase na relação entre populações de alguns estados brasileiros (anteriormente províncias), durante um longo período histórico: da primeira metade do século XVIII aos anos 50 do século XX. Nesse particular, ressaltamos a utilidade do conceito de sistema econômico regional. A propósito, vale citar Edgar Morin:

O sistema, como já foi dito - o todo - , é mais que a soma das partes, isto é, no nível do todo organizado há emergências e qualidades que não existem no nível das partes quando são isoladas. Tais emergências podem retroagir sobre as partes: a cultura é uma emergência social que retroage sobre os indivíduos, lhes dá a linguagem e o saber, e, por isso, os transforma. Não apenas o todo é mais que a soma das partes. Eu diria mesmo que o todo é menos que a soma das partes, porque tudo que é organizado tem obrigações, e tudo que é obrigação inibe ou proíbe possibilidades que não podem 
Revista de Antropologia, São Paulo, USP, 2003, v. 46 № 1.

ser exprimidas. (...) 0 objeto da ciência se transforma: não é mais algo isolado. 0 objeto da ciência é o sistema. (1999, p. 28-29)

É importante mencionarmos que, sob o conceito de sistema, estão implícitas as noções de inter-relação e interação. Ademais, estamos cientes da existência das partes que integravam o sistema econômico regional: na esfera da produção agropecuária, por exemplo, as culturas de vazante, os engenhos e engenhocas, os currais, as casas de farinha, a pesca; nos núcleos urbanos, as pequenas forjas, selarias, carpintarias, marcenarias etc.; no setor de transportes, as tropas de animais de carga, os carros de bois, as carroças, as barcas, ajoujos, paquetes, balsas e canoas. Nesse particular, não podemos perder de vista também a relação do sistema econômico regional com esse todo mais amplo que é a sociedade brasileira.

Em que pese a existência de informações sobre as barcas e seus tripulantes desde o século XVIII, este assunto permaneceu quase totalmente desconhecido dos estudiosos das Ciências Sociais até os anos 1990. Em sua obra 0 homem no vale do São Francisco, D onald Pierson e sua equipe citaram alguns trechos dos relatos de viajantes e técnicos sobre os remeiros (1972, p. 311-17, 552-57). Mas constataram a inexistência de estudos sistemáticos sobre 0 tema:

D urante numerosas décadas, um tipo ocupacional e social conhecido como "barqueiro", ou "remeiro", utilizou jangadas e outros barcos relativamente leves no São Francisco e seus tributários. A viagem rio acima era amiúde árdua e exigia grande dispêndio de energia até mesmo dos mais fortes, robustos e resistentes. Segundo soube o autor, nenhum estudo adequado foi jamais feito sobre o barqueiro, indivíduo tão pitoresco como economicamente importante durante o período em que trabalhou no São Francisco. (p. 311-12) 
Esse texto é, sem dúvida, um repto e um convite à reflexão sobre 0 trabalho dos remeiros, considerado economicamente importante pelos referidos autores. Mas as duas palavras citadas como sinônimos no texto acima têm significados diferentes na linguagem regional: 0 remeiro é 0 trabalhador que mourejava nas barcas; já o barqueiro era o proprietário da embarcação e comerciante. D iversos autores que escreveram sobre a região perceberam a diferença entre os dois termos. É importante conhecer, por exemplo, o livro de Edilberto Trigueiros (1977, p. 48 e 146), que fez uma pesquisa sobre a linguagem regional.

Antes de iniciarmos a interpretação da vida social dos remeiros do rio São Francisco, vale mencionar a origem dessa palavra, em desuso hoje na região. 0 termo remeiro possui origem latina; deriva da palavra remus (remi), da qual se originou o termo latino remex (remigis), que em português significa remador, remeiro (Saraiva, 2000, p. 1.020). Na segunda década do século XVI, G il Vicente já o utilizava em seu teatro/ poesia:

Remando vão remadores

barca de grande alegria;

o patrão que a guiava

filho de D eus se dizia;

anjos eram os remeiros,

que remavam à porfia.

Estandarte de esperança,

O h quão bem que parecia!

O mastro da fortaleza

como cristal reluzia;

a vela, com fé cosida,

todo o mundo esclarecia;

a ribeira mui serena,

que nenhum vento bulia. (Vicente, 1982, p. 63) 
Nesse texto de Gil Vicente, a palavra remeiros já parece indicar a existência de uma categoria profissional. No rio São Francisco, a classe social que era identificada por este termo, existiu ao longo de dois séculos: da primeira metade do século XVIII aos anos 50 do século XX. Nesses duzentos anos, os remeiros contribuíram para a integração das populações pertencentes aos estados (anteriormente, províncias) de Minas $\mathrm{Ge}$ rais, Bahia e Pernambuco.

Por fim, é importante esclarecer que, neste ensaio, o topônimo Alto São Francisco indica a área ribeirinha compreendida entre as nascentes e a cachoeira de Pirapora, incluídos os seus afluentes; o Médio São Francisco compreende a região intermediária banhada pelo rio, de Pirapora (MG) a Juazeiro (BA), acrescentando-se também os tributários; e o Baixo São Francisco, a área ribeirinha de Juazeiro até a foz, com seus afluentes. Vale mencionar que a expressão popular "Rio de Baixo" indica o trecho entre esta última cidade e a localidade de Jatobá (atual Petrolândia-PE).

\section{0 trabalho}

Se tomarmos os meios de producão como critério para interpretar a posição social dos remeiros, percebemos que eles integravam o contingente das classes subalternas que tinham em comum a condição de vendedores de força de trabalho. Os remeiros alugavam-se nas barcas de figura em troca de salários. Seus patrões, os barqueiros, faziam o comércio ambulante e transporte a frete ao longo da orla fluvial - em cidades, povoados, sítios e fazendas. A força de trabalho era contratada por viagem redonda, isto é, por jornada de ida ao porto de destino e retorno ao porto de origem. ${ }^{1}$ Se a viagem durasse três ou quatro meses, o salário não se alterava. Remunerava-se 0 trabalhador antecipadamente. No contrato 


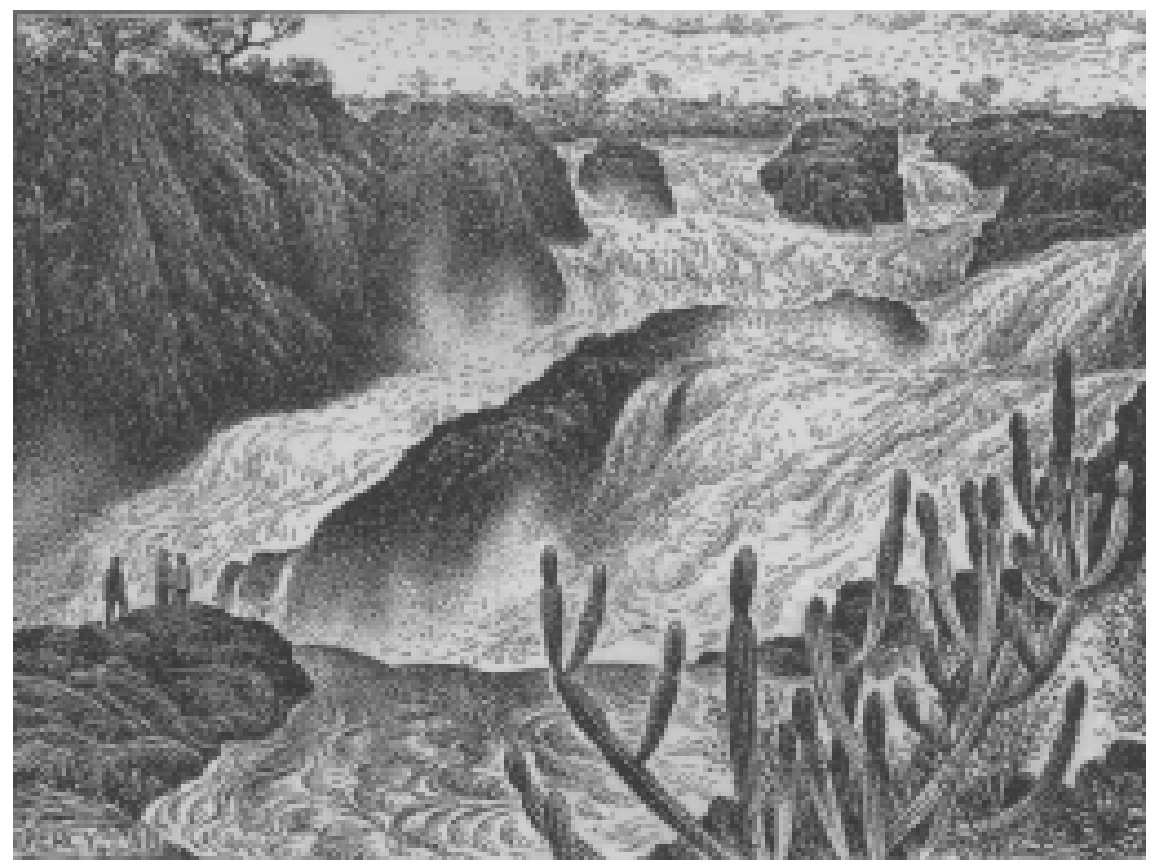

Cachoeira de Paulo Afonso. D esenho: Percy Lau (anos 1940).

verbal entre o remeiro e o barqueiro, pagava-se a metade do salário; no final da viagem, a outra metade. Essa forma do salariado revela de maneira bastante evidente que a força de trabalho é uma mercadoria.

Inicialmente, vamos conhecer o trabalho do neófito - o chamado reculuta (recruta) - na coxia das barcas conforme a terminologia criada pelos remeiros. ${ }^{2}$ Vejamos, a seguir, um trecho do conto regionalista de D. Martins de Oliveira, cujo teor está em consonância com os relatos que obtivemos em entrevistas:

Sua primeira viagem foi subindo o rio; custaram-lhe caro os primeiros dias de trabalho. Era demais pesado para sua mocidade manejar a zinga de sol a 
Revista de Antropologia, São Paulo, USP, 2003, v. 46 № 1.

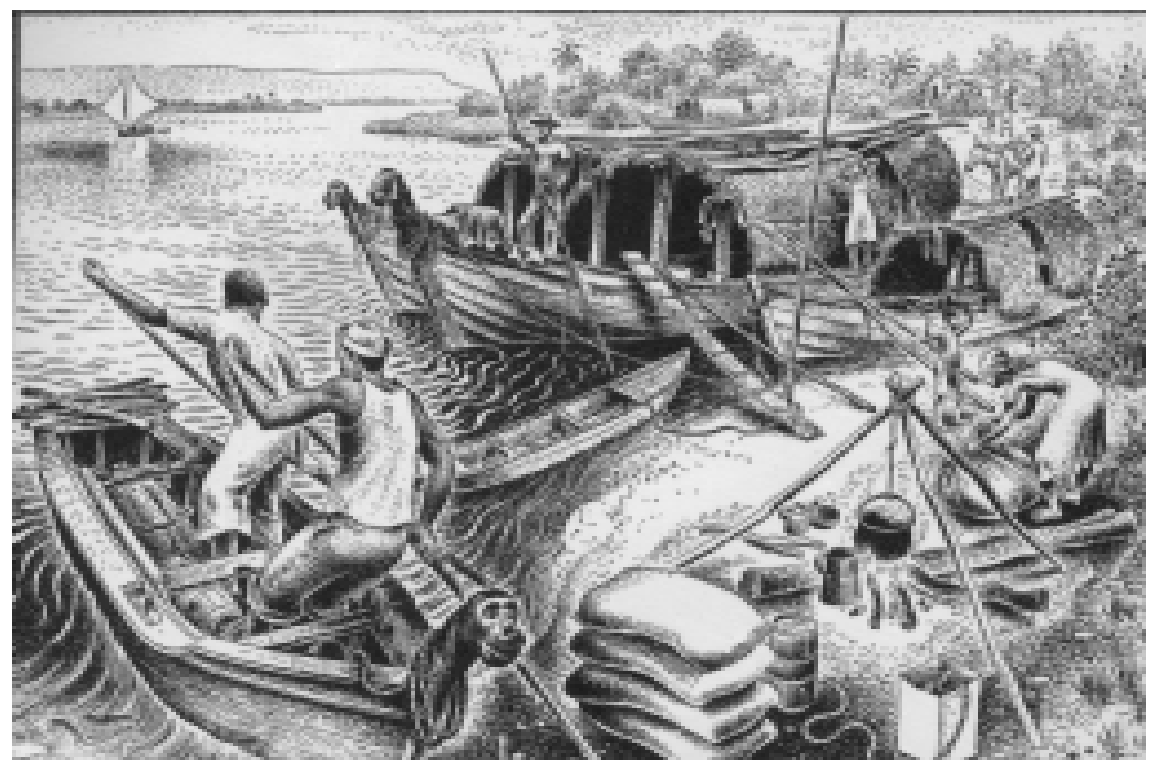

Cena fluvial com barcas de figura. D esenho: Percy Lau (anos 1940).

sol, carregando-a de popa à proa, levantá-la nos braços, atirá-la na água até que a ponta alcançasse o fundo, firmá-la ao peito e, com todo o esforço das pernas, impulsionar a lerda embarcação, em marcha continuada, incessante e mecânica de dínamo.

As mãos se lhe inflamaram, o peito abriu-se-lhe em chaga e, com três ínguas, a febre traumática o prostrava à noite. Q ueimou a ferida do tórax com sebo quente e no outro dia foi puxar a zinga do outro lado da coxia. (1931, p. 27)

A té a formação do calo no peito, o trabalhador passava por uma longa provação. Podemos dizer que era a sua iniciação. 0 sofrimento era indizível. Alguns não o suportavam e fugiam da tarefa. Aliás, a fuga era 
uma das formas mais comuns de resistência às más condições de trabalho. Além do sebo quente, o toucinho quente era também utilizado para cauterizar a ferida provocada pela vara. Às vezes, era necessário segurar firmemente as pernas e os braços dos reculutas, pois a terapia não era propriamente indolor. Se o remeiro persistia no trabalho, o ferimento inicial ia mudando de aspecto. Vejamos o que nos relata o contista Accioly Lopes: "O sangue pisado, fazendo ferida crônica - 0 grande medalhão com o qual o rio condecora a laia dos remeiros" (1978, p. 41). Ironicamente, a população ribeirinha se referia ao calo como a medalha e ao instrumento de trabalho (a vara) como a caneta.

É ainda Accioly Lopes quem assim resume o trabalho dos remeiros nas barcas de figura: "D obrando o peito que tine sobre a ponta da vara, ou acochando com os dedos duros do calejo o cabo do remo" (idem, p. 50). Nas viagens rio acima, utilizava-se 0 varejão (a vara ou vara ferrada) para impulsionar a embarcação; nas viagens rio abaixo, os grandes remos, que de um modo geral eram manejados por dois ou três homens.

Alguns cronistas em viagem pelo rio São Francisco descreveram também o trabalho dos remeiros. É importante conhecermos a narrativa do capitão D urval Vieira de Aguiar que lá esteve no princípio dos anos 80 do século XIX:

Munidos de grandes varas, ferradas na ponta, encostam a outra extremidade ao caloso peito, sem nenhum amparo, deixando muitas vezes, com 0 esforço, escorrer o sangue por garbo.

Enquanto os vareiros de bombordo empurram de proa a popa, os de estibordo voltam de popa a proa, de forma que uma banda só afrouxa as varas quando a outra as firma no leito do rio. (1979, p. 33) 
Revista de Antropologia, São Paulo, USP, 2003, v. 46 № 1.

O calo, que servia de anteparo no contato do instrumento de trabalho com o peito do remeiro, às vezes, fendia-se tendo em vista seu esforço para fazer a embarcação avançar rio acima, conforme relato de viagem de O rlando Carvalho (1937, p. 87). Eram comuns os sangramentos nessas ocasiões.

O s acidentes em que a vara se quebrava, e o corpo do trabalhador era traspassado pela lasca, são descritos nas entrevistas de ribeirinhos (Neves, 1998, p. 205-6). Mas a morte violenta está presente também no romance regionalista de O sório Alves de Castro: "Salu morreu arrebentado na zinga, botando sangue pela boca na água do Quebra-Botão" (s./ d., p. 19). Topônimo sempre presente no discurso dos remeiros, $Q$ uebra-botão era um trecho de água dura do rio Corrente onde os remeiros faziam um grande esforço para ultrapassá-lo nas viagens rio acima. 0 rio Corrente é um dos afluentes navegáveis do São Francisco à margem esquerda. Vale esclarecer também que zinga é a palavra erudita que o romancista utiliza em substituição a vara, varejão ou vara ferrada, de uso regional.

Na terminologia dos trabalhadores, vale destacar algumas expressões que identificavam itinerários: carreira grande designava a viagem de Juazeiro a Januária; meia carreira, de Juazeiro a Santa Maria da Vitória no rio Corrente; carreira inteira, de Juazeiro a Pirapora. Às vezes, utilizava-se esta última expressão para designar o itinerário de Juazeiro a Januária. A viagem a Barreiras era também considerada meia carreira. A duração de uma viagem a Santa Maria podia ser de um a dois meses; a Januária, de três a cinco meses. 0 comércio - a demora mais ou menos prolongada em cada porto para retalhar a mercadoria ou nas fazendas para comprar a produção - é que determinava o tempo de viagem.

No século XX, as áreas do Rio de Baixo e de Sobradinho eram as que ofereciam força de trabalho mais qualificada para a faina nas barcas. Mas em Juazeiro residia a maioria dos barqueiros e, por conseguinte, ali tinham lugar as contratações. Em Januária, Xique-Xique e Santa Maria 
da Vitória, era possível também recrutar remeiros experientes. Em meados do século XIX, o engenheiro Henrique Halfeld mencionou a possibilidade de contratação de trabalhadores em Barra do Rio das Velhas (atual Barra do Guaicuí-MG). Em 1748, D om Manoel da Cruz em sua viagem com destino a Mariana (MG) contratou nova equipagem naquela localidade (Ávila, 1967, p. 379).

No século XIX, era comum contratar-se trabalhadores por travessia, que em geral tinha a extensão média de 30 léguas marítimas, segundo Halfeld. Vejamos, a seguir, sua relação de travessias: a primeira, entre a cachoeira de Pirapora e a vila de São Romão, com 30 léguas de extensão; a segunda, de São Romão ao Porto do Salgado (atual Januária), com 26 léguas e meia; a terceira, de Salgado a Carinhanha, com 30 léguas e meia; a quarta, de Carinhanha a Bom Jesus da Lapa, com 24 léguas e meia; a quinta, da Lapa a Bom Jardim, com 26 léguas e meia; a sexta, de Bom Jardim à vila da Barra do rio Grande, com 29 léguas e meia; a sétima, de Barra a Pilão Arcado, com 29 léguas; a oitava, de Pilão Arcado a Sento Sé, com 31 léguas e meia; a nona, de Sento Sé a Juazeiro, com 18 léguas e meia (Halfeld, 1860, p. 1-2). Richard Burton legounos uma relação de travessias semelhante à de Halfeld. A creditamos que no século XIX os contratos por travessia eram regra geral apenas para 0 transporte de viajantes a exemplo de Burton e Halfeld. É possível que houvesse contratação de barcas por travessia, no transporte de cargas a frete. Na linguagem dos remeiros do século XX, era usual a palavra travessa; por exemplo: travessa da afinação, trecho entre Morpará e Bom Jardim (BA), e travessa da faca fora, trecho entre Bom Jesus da Lapa e Carinhanha (BA). Nesses trechos de nomes curiosos, não havia o auxílio dos ventos, os remeiros empurravam a barca rio acima, trabalhando com as varas de modo penoso.

Em seu romance Jandaia em tempo de seca, Petrônio Braz menciona o trabalho do mestre, ou seja, do piloto da barca: "Em pé, na popa elevada 
do modesto brigue, o piloto segurava o leme, manobrando com segurança os movimentos da embarcação" (2002, p. 60). Natural de São Francisco (MG), esse autor nasceu em 1928. É importante esclarecer que o leme da barca era um instrumento simples, feito de madeira e composto de duas partes: a cana do leme, que era empunhada pelo piloto, e 0 leme propriamente dito que ficava dentro d'água, movimentando-se lentamente à semelhança da cauda de um grande peixe. O s mestres evitavam os encalhes nos bancos de areia, as colisões em pedras e troncos submersos, manejando com habilidade esse instrumento de trabalho.

Os mestres e remeiros, que navegavam no Rio de Baixo, eram contratados também para a navegação do Rio de Cima, isto é, no trecho entre Juazeiro e Pirapora e em seus afluentes. Muitos deles eram contratados porque eram hábeis trabalhadores, por seu conhecimento das condições de navegabilidade.

Se o dono da barca tinha um comércio numa cidade ou vila, sua embarcação podia ser uma extensão ou filial do estabelecimento comercial. 0 proprietário, nesse caso, nomeava uma pessoa de sua confiança, que o substituía nas viagens comerciais. Podia ser um filho ou um parente próximo. Esse preposto chamava-se encarregado. O s remeiros ironicamente 0 chamavam de carregado.

Mas apenas os conceitos de meios de produção e relações de trabalho não são suficientes para interpretar a posição daquela classe social. A natureza do trabalho e sua marca no corpo do trabalhador, a cor da pele e o status inferiorizado possibilitam-nos entender a formação do estigma, que será interpretado mais adiante. 


\section{Negros e mestiços}

O s remeiros integravam o contingente de negros e mestiços que ocupavam posição social subalterna na região. A abolição da escravatura só alterou sua condição no que diz respeito ao regime de trabalho: do trabalho servil, passaram ao trabalho assalariado. Mas vale ressalvar que no período escravocrata havia também homens livres trabalhando nas barcas do São Francisco.

A presença de populações negras no Médio São Francisco é bastante remota. Em sua Relacão de uma missão no rio São Francisco, o padre Martinho de Nantes relata os primeiros contatos do homem branco com os índios cariris do São Francisco nos últimos anos do século XVII. Menciona também a existência de escravos negros que eram usados como força de trabalho nos curralos ou fazendas à margem do rio (Nantes, 1979, p. 52). Em 1867, sir Richard Burton correlacionava a cor da pele dos ribeirinhos com a posição social: "O s habitantes são todos mais ou menos escuros, (...) aqui o rosto mais claro é sempre indício de uma posição social mais elevada" (1977, p. 161). Os proprietários rurais e comerciantes - em geral, de origem portuguesa - eram brancos, ao passo que a massa de trabalhadores era constituída de escravos negros e mestiços. Mas havia homens livres, resultantes da miscigenação ancestral que ocorreu na região.

D esde o início da colonização do rio São Francisco, portanto, os negros ocuparam uma posição subalterna na estrutura social. Escravos até 13 de maio de 1888, passaram após esta data à condição de homens livres, isto é, trabalhadores que, em troca de alguma forma de remuneração, se empregavam na lavoura ou em pequenos ofícios urbanos como ferreiros, oleiros, aguadeiros etc. Não foi outro o destino dos afro-descendentes mestiços - os chamados mulatos e cafuz os nascidos na região. Trabalhavam a terra como parceiros, agregados, camaradas ou em pe- 
quenas unidades de produção familiar sem título de posse da terra. Muitos eram também pescadores.

D epois de se referir às condições de trabalho nas barcas, Teodoro Sampaio, que viajou pelo São Francisco em 1879, contribui com um texto primoroso para informar-nos acerca da composição racial da classe dos remeiros:

Vê-se ali, entre eles, todos os matizes da população policroma da nossa terra. 0 caboclo legítimo, o negro crioulo, o cariboca, misto do negro e do índio, o cabra, o mulato, o branco tostado de cabelos castanhos e às vezes ruivo, todas as raças do continente e os produtos dos seus diversos cruzamentos ali estão representados. (2002, p. 94-95)

Em seu conto "A araponga", Accioly Lopes confirma as informações de Sampaio e de nossos entrevistados:

Q uando acontece branco virar remeiro, que é o caso de Miguel Faiscô, aí a marca do trabalho toma outra feição. Tanto a ferida, quanto a estória. Remeiro, de modo geral, é sempre caboclo, negro ou mulato. Dizem que estes têm mais fibra. (1978, p. 19)

A primeira frase da citação acima parece denotar que a presença de homens brancos como força de trabalho nas barcas não era muito freqüente. A ferida a que se refere 0 autor é a marca da vara (instrumento de trabalho) no peito do trabalhador.

O s remeiros eram, sobretudo, negros e mestiços. Em sua viagem de canoa de Sabará ao Atlântico, Richard Burton teve a oportunidade de conhecer os escuros barqueiros, ou seja, os remeiros do rio São Francisco (1977, p. 209). 
As preocupações com origem e pureza racial estavam presentes entre as oligarquias da ribeira e expressam-se na literatura de ficção. Wilson Lins escreveu em seu romance Remanso da valentia:

D escendente de velhos sesmeiros reinóis, que se tinham deixado transformar em vaqueiros, nos primórdios da colonização, o velho O rmuth guardava o porte de um grão-senhor, orgulhoso de sua progênie, pelo que evitava o quanto possível entreter conversação com pessoas que não considerasse do seu nível.

(...) Fumando pacatamente o seu cigarro de palha, não estivera alheio de todo à troca de palavras havida entre o seu primo e os dois correligionários, embora se tivesse mantido ausente por não lhe agradar que um Castelo Branco de muitas posses, como o major O scar, estivesse perlengando com Fidelino e Antônio Borja, boas pessoas, é certo, mas, na sua opinião, dois mestiços sem tradição de família. (1967, p. 24-25)

Nos livros de Wilson Lins, o tema do coronelismo são-franciscano está presente. $\mathrm{O}$ referido autor fala com conhecimento de causa, pois era filho do coronel Franklin Lins de Albuquerque, chefe político de Pilão Arcado (BA) e aliado político dos Castelo Branco, de Remanso (BA), nas primeiras décadas do século XX.

Em estudo bem fundamentado, o professor Fernando Altenfelder Silva interpretou o preconceito racial existente em duas comunidades do Médio São Francisco: Xique-Xique e Marrecas (1961, p. 153-60). Edyla Mangabeira Unger surpreendeu-se com o preconceito explícito contra negros, observado em Lagoa de D entro (BA) (1978, p. 56-57). 


\section{Discriminação social e estigma}

Nas referências às barcas do Médio São Francisco, diversos termos foram utilizados para designar seus tripulantes. Cronistas dos séculos XIX eXX ora os chamavam de barqueiros, ora de remadores ou, até mesmo, de vareiros. As populações ribeirinhas, entretanto, preferiam a palavra remeiros para identificar aquela classe de trabalhadores do rio.

A partir da criação da Capitania dos Portos em Juazeiro (BA) nas primeiras décadas do século XX, um novo termo ganhou uso: mogos. Esta palavra, que passou então a ser utilizada pelos membros da classe dos remeiros para se auto-identificarem, advém possivelmente da expressão mogo de convés usada na referida instituição e de uso corrente nas empresas de navegação. No discurso dos ex-remeiros, nossos entrevistados, era também habitual o uso da expressão mogo de barca. Na verdade, os trabalhadores das barcas passaram a repudiar a palavra remeiro quando utilizada com sentido pejorativo nas cidades ribeirinhas. ${ }^{3}$ Já 0 termo mogo era a palavra-chave de sua identidade. Portanto, as palavras remeiro e moco (e moco de barca) podiam tornar-se antípodas e reveladoras da tensão existente entre aqueles trabalhadores do rio e segmentos da sociedade majoritária. Não raro, essa tensão descambava para o conflito.

No romance regionalista, pode-se perceber os contornos da posição social dos remeiros. Em Porto calendário, de autoria do senhor O sório Alves de Castro, um diálogo entre duas personagens mostra alguns traços das representações vigentes nas cidades ribeirinhas:

- Hum!... se faz? Remeiro já está desgraçando donzelas a troco de um pedaço de rapadura. Será que o tal século vinte será pior que os remeiros?

- Pior que o remeiro, só mulher desvalida... (s./ d., p. 21) 
Em nosso livro mencionado anteriormente, interpretamos esse diálogo incorporando entrevistas concedidas por ribeirinhos sobre os remeiros. Nesse particular, os casos regionais são valorizados como matéria de interpretação. Vale esclarecer que, na citação acima, as personagens conversam sobre 0 advento do século XX sem compreender muito bem do que se trata. Mas importante é perceber inicialmente os contornos da condição social a que se submetiam aqueles trabalhadores.

0 romance Porto calendário consegue caracterizar, em seus tracos fundamentais, 0 ethos da comunidade ribeirinha onde viveu seu autor: Santa Maria da Vitória (BA) às margens do rio Corrente. Mas outra contribuição muito importante de 0 sório Alves de Castro é tornar possível a reconstituição da vida social dos remeiros. Assim, a posição social daquela classe de trabalhadores tem seus contornos sugeridos pelo autor: "os dois rapazes se alugaram numa barca e ser remeiro era como se as criaturas perdessem a condição" (s./ d., p. 94). Trabalhar nas barcas implicava assumir um status inferiorizado do ponto de vista social e marcado pela discriminação e desqualificação social; enfim, pelo estigma.

Ao perguntarmos se os trabalhadores e seus patrões mantinham relações de compadrio, a resposta de um ex-remeiro foi negativa, acrescentando que os proprietários de barca os consideravam uma classe muito baix a. ${ }^{4}$ Mas as representações que denotam a posição social dos mocos de barca são reveladas não apenas por eles e seus patrões. Uma típica representante das camadas intermediárias, socializada no longo convívio com a gente ribeirinha, referiu-se aos remeiros como a última classe nas sociedades da região. "Q uando alguém não tinha mais nada a fazer na vida, ia ser remeiro." ${ }^{5}$ Percebe-se alguma coerência entre os discursos do ex-moço de barca e da entrevistada, pertencente a outra camada social.

Por intermédio do conto "A araponga", de Accioly Lopes, é possível conhecermos também o estigma que caracteriza a posição social dos moços de barca: 
Miguel Faiscô é remeiro. Remeiro do São Francisco não é gente. Não pode ser gente. Tem os pés redondos e frios como pacomão. Pés-de-mandiocapuba. Miguel sabe que é assim. Sabe. Por isso, sente-se, quando vestido de calção nu da cintura para cima, deslocado do mundo dos outros homens. (1978, p. 19)

Esta citação mostra-se coerente com os trechos de entrevistas já citados. Os próprios remeiros sentiam a discriminação, o estigma, que a sociedade lhes impunham. Daí, o conflito, a resistência.

Chamadas de couros e caboges nas cidades ribeirinhas, as prostitutas eram discriminadas do ponto de vista social. Mas as que mantinham relações sexuais com remeiros eram marcadas por uma desqualificação social adicional. Passavam a ser identificadas pelo epíteto mulher de remeiro - uma classificação depreciativa que lhes era atribuída pela sociedade majoritária. Na literatura popular, percebe-se esse fato. Vejamos, a seguir, a letra "L" do A BC do A ntônio M oniz, de autor desconhecido:

Lamentando a minha sorte

passei noite, passei dia

privado da liberdade

no meio daquela orgia

mulher-dama de remeiro

tem muito mais regalia. (s./ n./ t.)

0 poeta lamenta sua sina a bordo do vapor A ntônio M oniz comparando-a com a situação da mulher-dama de remeiro, cuja posição social era marcada pela discriminação e desqualificação nas cidades ribeirinhas. 0 fato de ser mulher de remeiro era um agravante para a sua condição de couro. Em entrevista, o comandante Francisco Leobas confirmou essa qualificação depreciativa imposta pela sociedade envolvente acrescen- 
tando que "mulher de remeiro era a mulher de segunda, desclassificada" . Esta expressão - mulher de remeiro - é mais uma informação reveladora da posição social dos remeiros e do estigma que a caracterizava.

D e um modo geral, a mudança de profissão implicava asœensão social dos remeiros; garantia-lhes algum prestígio no meio social. Alterava 0 seu status, que se tornava mais alto. 0 saber-fazer atinente à navegação, 0 conhecimento das condições de navegabilidade, que eles internalizavam arrastando vara na coxia das barcas, tornavam possível essa mobilidade social, na medida em que podiam ser incorporados às empresas de navegação como tripulantes dos vapores (gaiolas). Na profissão de vapozeiros, os ex-remeiros gozavam de maior prestígio nas cidades ribeirinhas. Mas, sintomaticamente, procuravam esconder sua condição social anterior, especialmente a medalha (calo formado pelo instrumento de trabalho) que poderia identificá-los socialmente como ex-remeiros. O termo "medalha" possui uma conotação jocosa. Esse sinal diacrítico - 0 calo - denunciava, de fato, a condição social de remeiro. A sociedade envolvente identificava-os e, até mesmo, discriminava-os ao constatar a existência do calo em seu peito revelando sua condição de piau. É importante conhecermos a tradução desta palavra da língua tupi para o nosso idioma: "Piau [adj.]: de pele suja, manchada, falando-se de peixes. 0 mesmo que ipiacu" (Bueno, 1984, p. 250). 0 piau é um peixe de água doce que tem duas manchas arredondadas nos flancos. Pertence à fauna do rio São Francisco, de seus afluentes e de outros rios brasileiros. Assim, comparava-se as manchas escuras do peixe com os calos negros provocados pelo instrumento de trabalho das barcas. Se os remeiros ascendiam socialmente, mudando de profissão, o velho estigma denunciava sua condição social anterior - a condição de piau. As lembranças permaneciam indeléveis. Nos tempos duros, podia-se ouvir do barranco quando uma barca ia passando: “Ô, piau porco d'água!". D aí, a necessidade de omitirem suas origens profissionais depois que mudavam de profissão. 
Revista de Antropologia, São Paulo, USP, 2003, v. 46 № 1.

No romance regional, é também mencionada esta característica da vida social dos remeiros: 0 estigma proveniente de sua vida profissional. É importante conhecermos, a seguir, um trecho de bilhete da personagem Lili ao seu namorado O rindo, ex-remeiro e protagonista do romance de O sório Alves de Castro, citado anteriormente: "Não acredito no que estão dizendo; que você tem no peito uma mancha de vara de remeiro do São Francisco. Tem horas que desejo cortar a língua de muita gente" (s./ d., p. 306). Nesse particular, a entrevista do comandante Francisco Leobas, que - diga-se de passagem - trabalhou em companhia de ex-remeiros nas empresas de navegação, é esclarecedora: "0 calo?... Mostravam... Mas pra quem eles tinham confiança. O compadre Leônidas, mesmo, mostrava. Agora, o desconhecido, se perguntasse: 'O sr. foi remeiro?' Eles diziam: 'Não interessa!'”. ' O velho estigma que havia submetido os remeiros à discriminação e desqualificação social no passado era percebido como uma ameaça em sua vida social no novo ambiente de trabalho - os vapores.

A discriminação incluía também uma referência jocosa ao varejão, ao qual a população ribeirinha se referia como a caneta. Se lembrarmos que os remeiros eram analfabetos, entende-se 0 teor da ironia.

Ao perceberem algumas características mais evidentes da posição social dos remeiros, alguns autores inadvertidamente os classificaram de párias (Trigueiros, 1977, p. 146), influenciados talvez pelo exemplo clássico de sociedades de castas: a sociedade indiana. Na verdade, aquela classe de trabalhadores estava integrada numa sociedade caracterizada por relações capitalistas; eram vendedores de força de trabalho que potenciavam a acumulação de capital numa escala bastante ampla, tornando possível a existência de algumas frações de classe constituídas por proprietários capitalistas: o barqueiro (comerciante ambulante), 0 grossista (atacadista) e, até mesmo, o exportador de couros, peles, borracha de mangabeira etc. A possibilidade de mobilidade social (ascensão 
social) nos termos em que a colocamos anteriormente não era comum na sociedade de castas indiana, por exemplo - o que se nos afigura uma diferença crucial entre 0 sistema de castas e 0 sistema social vigente no Médio São Francisco. Ademais, vale lembrar a religiosidade, diferente nas duas sociedades, e a prática endogâmica na sociedade indiana.

É evidente que, em sociedades onde o mando se sobrepõe às liberdades individuais e coletivas, a discriminação e a desqualificação social, que caracterizam o estigma, encontram campo fértil para proliferar; mas não são exclusivas deste tipo de sociedade.

O s remeiros não aceitavam passivamente o estigma...

\section{Os conflitos}

Uma das características da vida social dos remeiros era o seu comportamento violento nas localidades ribeirinhas, o que se pode perceber em relatos nas entrevistas (Neves, 1998, 209-27). 0 estigma explica, pelo menos em parte, essa agressividade. Sua presença nas cidades e vilas estava quase sempre associada a conflitos, seja com a polícia, seja com cidadãos comuns ou, até mesmo, com prostitutas. Nesse particular, é revelador um texto do escritor Wilson Lins em seu livro 0 Médio São Francisco: uma sociedade de pastores e guerreiros:

Trazendo em si todas as qualidades viris do curiboca nordestino, ele é excelente matéria-prima para o cangaço. Com todos os traços característicos do jagunço, o remeiro é um valente, e não só nas lutas contra o rio e as corredeiras. Sua arma predileta é a peixeira, faca de ponta fina e lâmina larga. Nas desordens de casa de raparigas, a peixeira funciona sem piedade, mandando para o outro mundo quantos invistam contra o cabra-remeiro. (1960, p. 132) 
Esses conflitos ocorriam, sobretudo, com os paisanos do comércio, isto é, com aqueles moradores das localidades ribeirinhas, que freqüentavam as chamadas zonas (do meretrício) e as chamadas brigas de jegue. Esta última expressão, eivada de preconceito, era utilizada por integrantes das elites ou das classes intermediárias para designar os bailes de pessoas humildes e os arrasta-pés nos prostíbulos. ${ }^{8}$

A intervenção policial nos conflitos só fazia botar mais lenha na fogueira, ampliando o furdunœo, com as conseqüências previsíveis: a ocorrência de mortes e ferimentos. Em substituição à faca peixeira ou à lambedeira, os remeiros portavam também um cacete, utilizado nessas rixas para a solução das desavenças. ${ }^{9}$

Uma palavra veiculada no discurso dos nossos entrevistados caracteriza significativamente as representações da classe acerca dos policiais que os reprimiam, revelando a tensão entre as duas partes. A palavra é macaco - sempre utilizada em sentido depreciativo.

No Médio São Francisco, há um ditado popular - relembrado pelos barranqueiros mais idosos - que pontifica: "remeiro na areia/ mulherdama na peia". Em que pese o duplo sentido que vislumbramos nesse ditado, o significado literal é bastante evidente e foi amplamente confirmado pelos nossos informantes: os conflitos entre os remeiros e os couros (as prostitutas) eram freqüentes e, não raro, provocavam a intervenção policial. 0 termo peia é sinônimo de surra, chicote. Mas vale mencionar o outro significado: peia é um sinônimo popular de pênis. Nesse particular, o ditado diz respeito ao relacionamento sexual dos remeiros com as prostitutas.

Referindo-se aos conflitos com os soldados da polícia do estado da Bahia, um dos nossos entrevistados afirmou que os tripulantes das barcas "não respeitavam polícia". Por outro lado, é importante ressaltar um trecho de depoimento que contribui para revelar as representacões e práticas sociais acerca dos remeiros: "Diante de todos os sacrifícios (o tra- 
balho na coxia das barcs), eram repudiados pelas sociedades da região e perseguidos pela polícia como desordeiros ${ }^{\prime \prime} .{ }^{10}$ Menciona-se a existência de repúdio que revela a desqualificação social bem como a ocorrência de perseguição policial nas cidades ribeirinhas. É importante esclarecer que as sociedades da região eram as elites daquelas localidades, pertencentes às oligarquias e às camadas intermediárias que gravitavam em seu redor.

As entrevistas e depoimentos são coerentes com o relato de sir Richard Burton acerca da vida social dos remeiros: " 0 pessoal não gozava, em absoluto, de bom oncito e contavam-se vários casos de barqueiros roubando de seus patrões e os deixando limpos. Bebem e são perigosos" (1977, p. 295). Bom concito indica a existência de status respeitável, de integração ao meio social, o que não era o caso dos moços de barca. É importante esclarecer que, ao mencionar os barqueiros, Burton se refere aos tripulantes das barcas.

Com referência aos roubos, ouvimos o relato de um caso muito difundido entre os remeiros e vapoz eiros do São Francisco. Alguns portos onde o comércio era intenso, como Januária, Barra, Santa Maria, Barreiras, concentravam um grande número de embarcações. Havia um remeiro que freqüentemente saía de sua embarcação para furtar em outras barcas. Quando ele voltava com um saco de farinha nos ombros, seus companheiros the perguntavam: "O nde você conseguiu esta farinha?". Ele prontamente respondia, sempre com muita graça: "Peguei com a tarrafa!".

O viajante inglês (Burton) não esclarece, entretanto, por que os remeiros eram perigosos. Em nossas entrevistas, tivemos a oportunidade de colher outras informações acerca da vida social dos remeiros. Ex-proprietário de barca, o senhor Wilson Castelo Branco se referiu àqueles trabalhadores como a escória da sociedade; e, com indignação, responsabilizou-os pelo assassinato de um outro dono de barca, natural de Remanso (BA), cujo nome era Amaro. ${ }^{11}$ No conto regionalista "Barca 
Revista de Antropologia, São Paulo, USP, 2003, v. 46 № 1.

fantasma", a fala de um personagem remeiro contribui também para esclarecer-nos acerca da citação do viajante inglês em consonância com a entrevista do senhor Castelo Branco:

- Quá! Cum esse home nós não trabaiava nem amarrado, falou um dos remeiros. Cosia logo a barriga dele c'a língua da faca! O ra e veja! Patrão é patrão: tem qui andá dereito c'a gente, pra se podê sê correto cum ele! Quem qui é cachorro pra aguentá? (Oliveira, 1931, p. 39-40)

A disposição dos mogos de barca para a violência física fica evidenciada nessa citação do conto de D. Martins de Oliveira, escritor nascido e educado em Barra (BA), cidade ribeirinha do São Francisco.

Alguns termos e expressões - presentes em entrevistas - eram utilizados pela sociedade majoritária para discriminá-los: porco d'água, pé pubo, piau, pé de prancha, burro d'água, bicho d'água etc. Estes vocativos e epítetos partiam do barranco, do cais e dos vapores em direção às barcas. Em sentido contrário, espoucavam os palavrões visando, sobretudo, a mãe do interlocutor. Se houvesse oportunidade, a violência não ficava limitada em nível apenas verbal. Era comum também a violência física.

A disposição psicológica para o revide às ofensas e à discriminação social está contida nos versos abaixo, de autoria dos remeiros:

Só quero ter vida e saúde

enquanto for respeitado. ${ }^{12}$

D e todos os lados partiam pilhérias, apelidos e troças dos beiradeiros e dos vapozeiros (tripulantes dos vapores). Assim, os versos acima revelam de maneira subjacente uma carência na vida dos remeiros: 0 respeito da sociedade. Mas há também a disposição para a resistência. 
No conto "Pedro Barqueiro", que se tornou um clássico da literatura brasileira, Afonso Arinos - escritor nascido em Paracatu (MG) - mostra as origens do protagonista e uma característica de sua personalidade:

D aí, ainda contavam muita valentia do Barqueiro, nome que lhe puseram por ter vindo dos lados do Rio S. Francisco. (...)

Um dia, como já lhe contei, apareceu lá em casa um moço pedindo auxílio a meu patrão para agarrar o negro. Era mesmo escravo, o Barqueiro; mas há muitos anos vivia fugido. (s./ d., p. 95-96)

A caracterização do personagem corresponde à realidade, ao tripulante de barca do rio São Francisco:

Crioulo retinto, alto, troncudo, pouco falante e desempenado. Cada tronco de braço que nem um pedaço de aroeira.

Estou com ele diante dos olhos, com aquela roupa azuleja, tingida no Barro Preto; atravessado à cinta um ferro comprido, afiado, alumiando sempre, maior que um facão e menorzinho do que uma espada.

Este negro metia medo de se ver, mas era bonito. Olhava a gente assim com ar de soberbo, de cima para baixo. Parecia ter certeza de que, em chegando a encostar a mão num cabra, o cabra era defunto. (idem, p. 94-95)

O ferro descrito pelo grande contista era possivelmente a temida lambedeira que os remeiros costumavam usar nas cidades ribeirinhas. Em substituição a essa faca, era comum utilizarem-se também de um cassetete. O utras características do personagem merecem nossa atenção tendo em vista a semelhança com os embarcadiços das velhas emas: negro, forte, arrogante... O u melhor: resistente!

Por fim vale conhecer como repercute no referido conto esta característica marcante da vida social dos remeiros: 0 conflito, a violência. 
Chegara uma precatória da Pedra dos Angicos e o juiz mandou prender a Pedro. D eram cerco à casa onde ele estava na noite do batuque. (...)

Q uando cercaram a casinha e lhe deram voz de prisão, o negro fechou a cara e ficou feito jacaré de papo amarelo. (...)

Chegaram a entrar na casa três homens da escolta, e todos três ficaram estendidos. (idem, p. 95)

É importante esclarecer que Pedra dos Angicos é o antigo nome de São Francisco (MG), cidade ribeirinha. A comparação do remeiro com animais ferozes aparece também nas entrevistas: "remeiro era caça que cachorro acuava" - dizia-nos o senhor Antônio Joaquim dos Santos, ex-barqueiro, em Remanso (BA).

No romance regional, estão presentes também o conflito e a violência. Em 0 reduto, Wilson Lins contribui para reconstituirmos algumas características da vida social daqueles trabalhadores. Ex-remeiro, o personagem Pedro Gamela vive com uma prostituta e comete um assassinato arremessando um chuço de pesca contra um jovem em Pilão Arcado (BA). Em Remanso da valentia, outro romance que compõe a trilogia do mesmo autor, o referido personagem morre em circunstâncias trágicas, vítima de sua personalidade violenta. Esses fatos são reveladores da tensão entre a classe dos remeiros e a sociedade envolvente. Nesse mesmo romance, a linguagem de Pedro G amela denota sua índole e suas origens:

- D esn'antonte que não tenho sossego, e se já subesse dessa traiança no dia em que fui à Vila, em vez de voltar pra cá, eu tinha era ficado lá, mas era na cadeia, pois havera de comer na faca aquele doutorzinho de merda! - rugia o negro, enraivado, numa voz abafada. (Lins, 1967, p. 143) 
Entre os vapozeiros do rio São Francisco, circulava uma anedota cujo protagonista era um remeiro; seu apelido, Jacuba. Esta anedota revela a disposição dos remeiros para a violência física. Vale mencionar que a jacuba fazia parte da alimentação diária daqueles tripulantes das barcas. Consiste basicamente na mistura de farinha de mandioca, rapadura raspada e água. Certa vez, um barranqueiro tomou um prato; dentro dele, colocou um pouco de farinha, acrescentando uma porção de raspas da boa rapadura de Januária. Q uando ia derramar a água da caneca no prato, ele ouviu a ameaça: "Se misturar, morre!". Era o remeiro Jacuba que repudiava com veemência seu apelido, ainda que não pronunciado verbalmente, não permitindo, até mesmo, que o alimento fosse preparado à sua frente.

O cais dos portos, as zonas (prostíbulos), as vendas, onde se comprava cachaça, constituíam os locais que os remeiros freqüentavam nas cidades ribeirinhas. Ali desenvolviam sua sociabilidade; ali firmavam sua identidade ante os grupos sociais com os quais conviviam. Mas ali também ocorriam os conflitos.

Na seção seguinte, descrevemos o local de trabalho dos remeiros, isto é, a barca onde contribuíram para a integração de uma vasta região do Brasil.

\section{As barcas}

Em 1748, dom Manoel da Cruz partiu do Maranhão com destino a Mariana, província de Minas Gerais, para tomar posse no novo Bispado marianense. $O$ relato da viagem encontra-se no documento histórico denominado Á ureo Trono E piscopal (Ávila, 1967). D om Manoel viajou pelo interior da colônia chegando à confluência do rio Preto com o rio Grande, que por sua vez deságua no São Francisco. O senhor Bispo e 


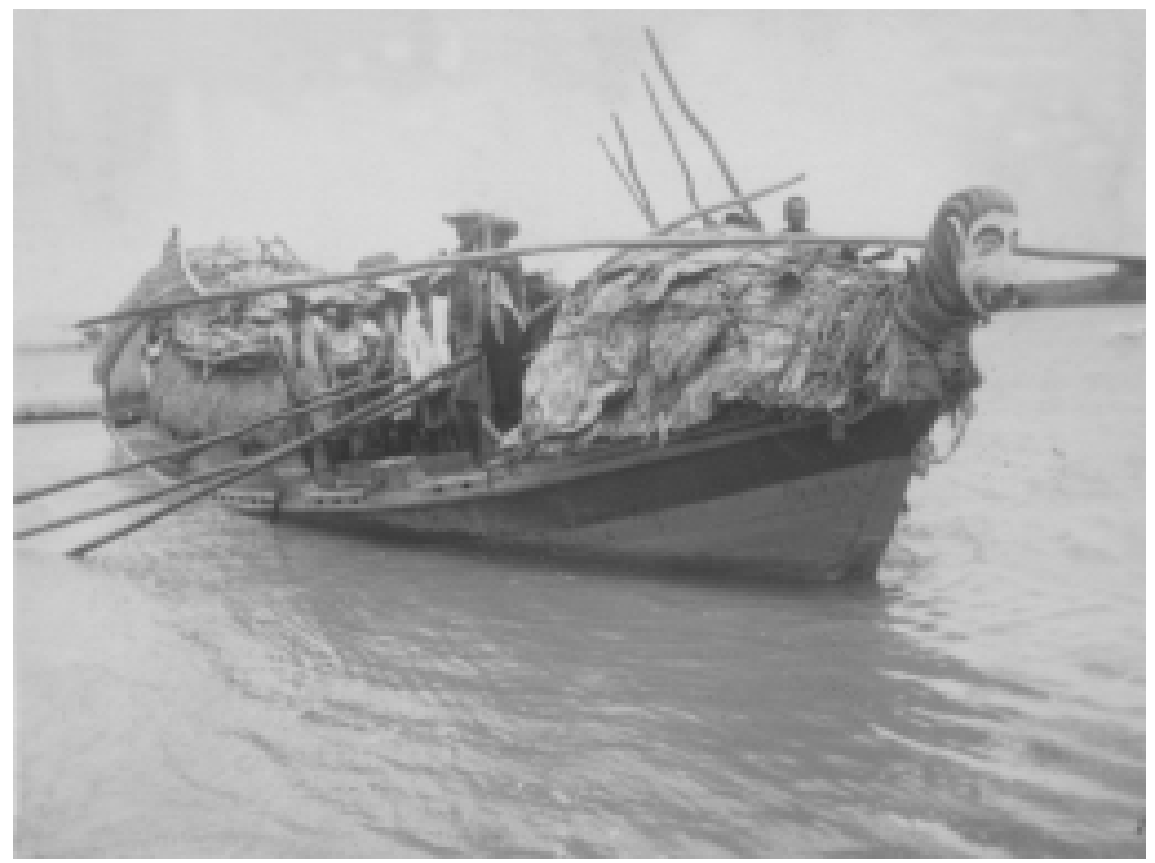

Os remeiros e a barca. Fotografia: Comandante Joaquim Borges das Neves (1939).

sua comitiva ocuparam duas barcas percorrendo aproximadamente $1.800 \mathrm{~km}$ até alcançar Sabará (MG ), às margens do rio das Velhas, outro tributário do São Francisco (idem, p. 373-80). Vejamos, a seguir, um breve trecho do relato de viagem:

As barcas seguiam um canal pelo meio do rio, e dos lados ficavam dois bancos de areia que impediam buscar a terra para dar fundo. Com grande susto, venceu S. Excelência o dito canal e tomou porto duas léguas abaixo da Carunhanha, mas ficou embarcado na sua barca, e a sua família, em outra. (idem, p. 375) 
É provável que em 1748 já houvesse barcas realizando o transporte regular de cargas no São Francisco. O s tripulantes das embarcações que transportavam dom Manoel e sua comitiva deveriam ser profissionais experientes. É importante esclarecer que Carunhanha é o nome antigo da atual Carinhanha (BA).

Residente em Barra (BA) no século XIX, Thomaz Garcez Paranhos Montenegro confirmou a existência de barcas na segunda metade do século XVIII, mencionando seus nomes sem deixar de citar seus proprietários: Santa M aria I, de João Maurício da Costa e José de Mattos, de Sento Sé (BA); Claro D ia, propriedade de Antônio de Souza e Mendonça da Cunha; e São José, de José Lopes, da fazenda Jequitaia em Sento Sé (BA) (Montenegro, 1875, p. 134-35). De um modo geral, as barcas de Sento Sé dedicavam-se ao transporte do sal da terra produzido em suas imediações.

Na segunda metade do século X IX, os barqueiros adotaram a figura, hoje conhecida como carranca. Um dos primeiros cronistas a mencionála foi D urval Vieira de Aguiar em 1882: "Na proa vê-se uma carranca ou grifo de gigantescas formas, de modelos sem dúvida transmitidos pelos exploradores dos tempos coloniais" (1979, p. 33). Figura, figura de proa e leão de barca são os termos ou expressões que os remeiros e outros ribeirinhos utilizavam para se referirem às carrancas. Mas vale atentar para outras informações de Aguiar acerca das barcas:

Vista de perto assemelha-se grosseiramente a uma das lanchas de nossa cabotagem marítima, porém sem mastros, tendo à ré alto e comprido camarote, com portas e janelas, e de um tamanho que absorve pelo menos um terço da barca em cujo camarote fazem armações internas para os gêneros, se porventura a barca é de negócio; havendo algumas em que o camarote forma como que uma grande arca quase do comprimento da barca, a fim de melhor abrigarem as fazendas. (idem, 1979, p. 32) 
A maioria das barcas possuía uma tolda coberta de palha de carnaúba, a qual 0 autor chama de camarote. Na proa, havia um compartimento menor a que os remeiros davam o nome de murundu. 0 leme ficava na popa, um espaço descoberto onde o mestre (piloto) trabalhava. O s remeiros mourejavam nas cox ias, ou seja, nos espaços laterais a bombordo e a boreste. Como se pode perceber no texto acima, algumas embarcações faziam o comércio de tecidos.

Vejamos agora a presença da barca num romance, Paix ões alegres, recentemente lançado, cujo autor é natural de Januária (MG):

Em tempos mais afastados ainda, bem anteriores ao meu nascimento, meu avô paterno transitava pelo São Francisco nas velhas barcas de carrancas monumentais na proa. Ele era proprietário de uma delas e fazia o comércio ribeirinho transportando cereais, rapadura, sal, querosene e outras mercadorias do consumo barranqueiro. D ez, doze remeiros compunham a tripulação que subia e descia o rio singrando a corrente a muque, tangendo a embarcação à força do movimento ritmado dos varejões e remos. (Souza, 1996, p. 11-12)

0 escritor menciona alguns produtos que de fato as barcas transportavam, mas não se pode perder de vista a borracha de mangabeira e maniçoba, os couros e peles, o café, a farinha etc. 0 referido romance possui traços autobiográficos.

No romance M aleita, Lúcio Cardoso descreve o povoado de Pirapora (MG) nos últimos anos do século XIX. Nesse particular, vale conhecer a referência a seu porto: "O rio era evidentemente o fator principal da vida no lugarejo. Trazia de longe os barcos semicarcomidos, navegando lentos por causa da água que sacolejava no bojo apodrecido, a cabeça de cachorro na proa, balançando ao vaivém da maré" (s./ d., p. 52). 
O s barcos a que se refere 0 autor eram precisamente as embarcações acima mencionadas, que faziam o transporte a frete e o comércio ambulante ao longo do rio; a cabeça de cachorro era a figura de proa. $\mathrm{Na}$ tipologia criada para classificar as carrancas, a figura de cachorro, mencionada por Lúcio Cardoso, seria incluída no tipo zoomorfo. Marcel G autherot fotografou uma barca cuja figura foi esculpida em forma de cabeça de cavalo (G autherot, 1995, p. 94). Mas havia dois outros tipos de figura: a antropomorfa (mais rara) e a zooantropomorfa. Este último tipo era mais comum. As esculturas desse tipo, fotografadas também por $\mathrm{G}$ autherot (idem, p. 88-90), possuíam características de animais e de seres humanos (Pardal, 1974). Em entrevista concedia pelo exremeiro Emídio Lopes da Silva, ouvimos referência a uma figura de proa do tipo antropomorfo - uma cabeça de mulher. ${ }^{13}$ Mas pelo menos um barqueiro colocou um chifre de boi na proa de sua embarcação em substituição à tradicional figura. Os chifres estão também nas cercas de algumas propriedades rurais do Médio São Francisco - no sistema de crenças regional, são a garantia de proteção contra o mau olhado. Acreditava-se que as figuras de proa protegiam as barcas, inclusive contra os seres míticos do rio.

Em outro trecho do seu livro, Lúcio Cardoso mencionou especificamente uma barca que partia do povoado de Pirapora: "A 'Sant'Ana da Lagoa' voa sobre a corrente" (s./ d., p. 102). Petrônio Braz cita em seu romance uma barca cujo nome encontrava-se efetivamente registrado nos arquivos da $\mathrm{C}$ apitania dos Portos em Juazeiro (BA): "Os seus doze metros de comprimento por dois de largura estavam pintados de vermelho vivo, em toda parte visível acima da linha d'água. Na proa, atrás da carranca, lia-se um nome: G aivota" (2002, p. 60). No bojo da G aivota, a barca do romance do senhor Braz viajava uma carga de rapaduras alimento básico dos ribeirinhos. 
As barcas cumpriam também funções paramilitares nas lutas entre coronéis do Médio São Francisco. No romance Militão sem remorso, de Wilson Lins, a fala de um personagem (comendador) em conflito com outro chefe local é reveladora: "Cabras não me faltam, nem munição, e estou com a barca cheia, para atacar o Campo de Fora, hoje à noite" (1980, p. 95). Os remeiros podiam alinhar-se nas hostes de um grupo de parentesco, comandadas por um coronel, ou sob as ordens do patrão (barqueiro), conforme entrevistas (Neves, 1998, p. 150).

Em nosso livro, descrevemos as barcas no capítulo III. Por intermédio dessas embarcações e dos meios de transporte terrestres, formou-se e desenvolveu-se 0 sistema econômico regional.

\section{A integração inter-regional}

No princípio do século X IX, os cientistas Spix e Martius registraram em seu livro algumas informações da A lfândega de Malhada sobre as atividades de importação e exportação da Província de Minas Gerais por intermédio do rio São Francisco. É importante esclarecer que essa alfândega localizava-se às margens do grande rio, nas proximidades da divisa entre as três províncias: Minas, Bahia e Pernambuco. 0 sal da terra foi 0 principal produto importado nos períodos de abril a setembro de 1816 e de outubro de 1816 a março de 1817, se considerarmos o volume em arrobas e quantidade de sacas. Mas o valor dos objetos de fabricação européia, sobretudo tecidos, superava largamente o montante pago pelo sal nos dois períodos, em que pese a grande diferença em termos de volume. Portanto, vale ressaltar que muito remotamente os produtos da Revolução Industrial expandindo-se pelo mundo já ganhavam o mercado do Médio São Francisco, utilizando as barcas como meio de transporte. As elites regionais vinculavam-se como consumidoras ao mercado 


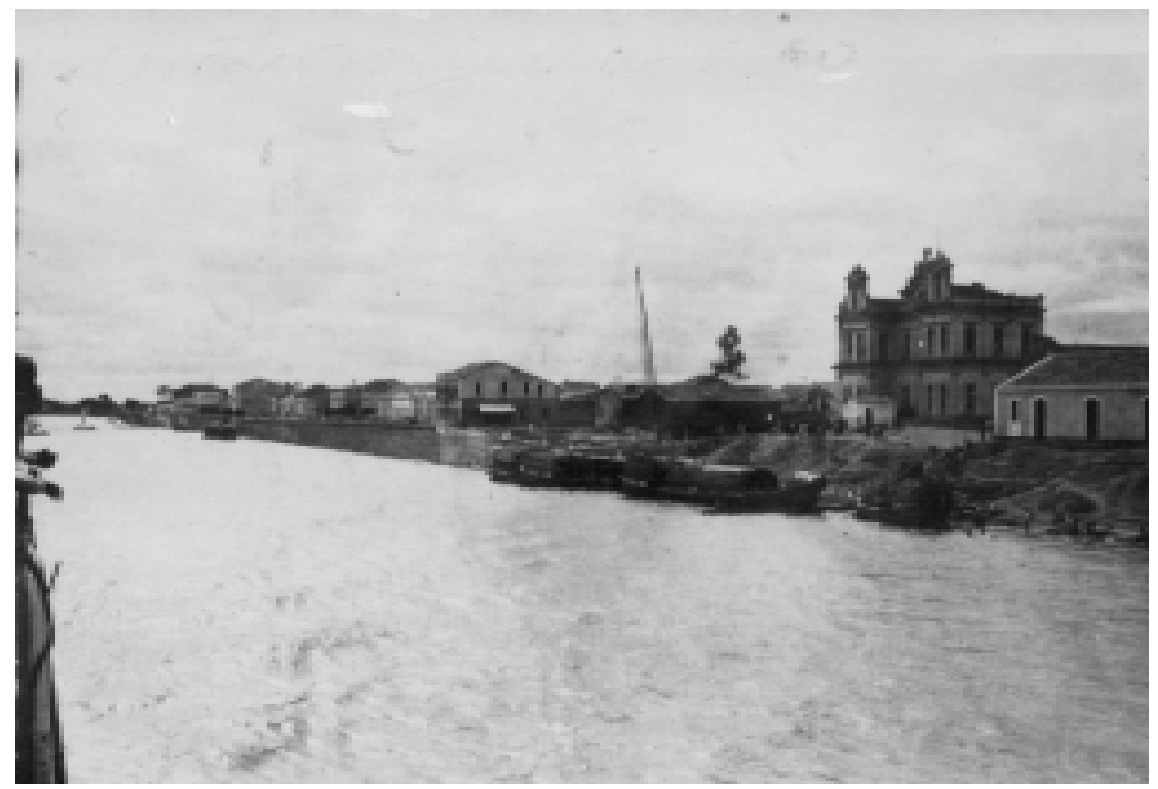

Porto de Juazeiro-BA

Fotografia: Comandante Joaquim Borges das Neves (1939).

internacional que então se desenvolvia. A tabela de exportação da Província de Minas G erais no período de abril a setembro de 1816 revela a predominância de dois produtos: rapadura e farinha de mandioca, alimentos básicos dos ribeirinhos (1981, p. 41-48).

Monsenhor José de Souza Azevedo Pizarro Araújo, cuja obra publicada em 1822 demonstra um significativo conhecimento deste autor sobre a região do Médio São Francisco, apresenta-nos algumas informações de natureza econômica, ressaltando as articulações regionais e inter-regionais que então se operavam na Freguesia da Barra (atual Barra do Guaicuí-MG): 
(...) se conserva nesse lugar mui florente comércio, sendo o maior dos gêneros o sal transportado do Rio S. Francisco. (...) Foi esta povoação a primeira do sertão na margem oriental do Rio das Velhas, mui populosa e comerciante, quando os habitantes das G erais, e G oiás, faziam por aí caminho para a Bahia. (1822, p. 175)

Ao mencionar o sal "transportado do Rio S. Francisco", implicitamente 0 autor se refere aos meios de transporte que então se utilizavam - as barcas e os ajoujos. Vale esclarecer que o sal mencionado pelo monsenhor Pizarro é o sal da terra extraído das salinas de Sento Sé, Pilão Arcado, Campo Largo etc., então pertencentes às províncias da Bahia e de Pernambuco. É possível que "os habitantes das G erais e G oiás" utilizassem também as referidas embarcações para chegar à Bahia.

Sem ter visitado a Freguesia da Barra no princípio do século XIX, Augustin Saint-Hilaire permite-nos o acesso a conhecimentos acerca da integração daquele povoado com regiões adjacentes - estribado possivelmente em informações de ribeirinhos residentes em Salgado (atual Januária-MG) onde ele esteve:

D evo lamentar, todavia, não ter visto a povoação de Barra, que está situada na confluência do Rio das Velhas e que, estando mais perto que Salgado e S. Romão de Tejuco, Vila do Príncipe, Vila Rica, recebe maior número de tropas de cargueiros e entretém um comércio importante com a região das salinas. (1975a, p. 354)

É importante esclarecer que Tejuco é o antigo nome de Diamantina (MG); Vila Rica é o antigo topônimo de O uro Preto (MG); e a Vila do Príncipe deve ser Paracatu do Príncipe (MG). Certamente em grande número, as tropas de mulas visitavam a povoação de Barra. Portanto, vale ressaltar o papel social dos tropeiros no sistema econômico regional. Por 
outro lado, Saint-Hilaire confirma as informações do monsenhor Pizarro: a Freguesia da Barra recebia o sal da terra mantendo "um comércio importante" com os povoados salineiros por intermédio das barcas. Mais de $1.000 \mathrm{~km}$ de trecho navegável - vale esclarecer - separam Barra do Guaicuí da sub-região das antigas salinas. Todo esse percurso era beneficiado pelo comércio realizado pelas barcas. A té mesmo produtos estrangeiros chegavam à Freguesia da Barra conforme sir Richard Burton que a visitou em 1867: "Meu companheiro comprou em sua loja (do delegado) uma peça de algodão, com a marca J. Branley Moore; estava cheia de goma, leucomaína e dextrina, em triste contraste com o bom produto caseiro de Minas" (1977, p. 163). Em que pese a qualidade superior do tecido artesanal, ressaltada na citação, o produto industrializado foi responsável por seu desaparecimento.

A descoberta do ouro em Paracatu data da primeira metade do século XVIII. Em pouco tempo, o povoado alcançaria, na região, status de importante centro econômico, cujo consumo de bens e serviços parece refletir a opulência de seus grupos sociais hegemônicos. Vejamos, nesse sentido, o que afirma Saint-Hilaire:

Pagando altas tarifas, eles importavam vinhos e outras mercadorias da Europa, que ali chegavam varando os sertões. G randes somas de dinheiro eram despendidas com as festas da igreja, contratavam-se músicos, construiu-se um pequeno teatro, e os próprios escravos, em suas folganças, espalhavam - segundo se conta - ouro em pó sobre as cabeleiras de suas melhores dançarinas. (1975b, p. 148)

É provável que, no século XVIII, os "vinhos e outras mercadorias da Europa" chegassem a Paracatu a bordo das barcas, depois de passar pela A lfândega de Malhada. 
Segundo informações legadas por monsenhor Pizarro, a população de Paracatu em 1766 constava 12 mil habitantes (Araújo, 1822, p. 213) - um número bastante significativo, se comparado a outros povoados da colônia, e um mercado consumidor importante.

Além do ouro encontrado em seus córregos e riachos - sobretudo no córrego Rico -, Paracatu passou a produzir, no século XVIII, gêneros alimentícios cujo excedente era exportado para o Médio São Francisco e áreas adjacentes. Vejamos, nesse particular, o que afirma Saint-Hilaire, que esteve na sub-região de Paracatu em 1819:

D epois que os habitantes da região de Paracatu passaram a cultivar regularmente suas terras, os que habitam as margens do S. Francisco vêm sempre comprar em suas mãos o milho, o feijão, o açúcar e a aguardente, trazendo em troca o sal de Pilão Arcado. Durante o tempo que passei em Paracatu encontravam-se ali vários comerciantes de Caiteté, empenhados em comprar víveres. (1975b, p. 152)

É importante esclarecer que Caiteté (BA) não é cidade ribeirinha; localizava-se, na verdade, a uma distância de aproximadamente $180 \mathrm{~km}$ do porto de Carinhanha (BA). Menor distância a separava de Bom Jesus da Lapa (BA), outro porto fluvial do Médio São Francisco. Vale ressaltar o papel social dos barqueiros levando o sal da terra e comprando outros produtos.

Paracatu não só produzia, mas também recebia mercadorias de outras povoações não ribeirinhas servindo, inclusive, de empório intermediário para a exportação de gêneros de plantação do Julgado de Araxá (O este de Minas) para localidades do Médio São Francisco, conforme crônica do ouvidor Antônio Paulino Limpo de Abreu na segunda década do século XIX (apud Gonzaga, s./ d., p. 30). 
Vale esclarecer que Paracatu não é cidade ribeirinha, mas tinha seu porto no afluente de mesmo nome. D iversos autores se referiram a Buriti a 8 léguas da sede do município como o porto de Paracatu. Apenas monsenhor Pizarro citou o "Porto de Bezerra onde as barcas do rio São Francisco, e as canoas, levam o sal, pelo qual permutam o açúcar, 0 toucinho, aguardente, café, queijos e vários outros gêneros de exportação" (A raújo, 1822, p. 218). Esse porto localizava-se a 12 léguas da sede da vila, segundo o referido autor, cujos relatos datam de 1822.

Nos primeiros anos do século XIX, o mesmo cronista mencionou a posição estratégica de São Romão, pelo prisma econômico, como importante núcleo de articulações inter-regionais: "D o produto das salinas cultivadas nas capitanias da Bahia e de Pernambuco, sobem para aí (São Romão) carregadas muitas barcas e canoas cujo gênero compram os nego ciantes tropeiros para levá-lo às povoações das gerais e às minas de Goiás" (idem, 1822, p. 220).

Cabe enfatizar que o sal produzido nos povoados ribeirinhos não era consumido apenas no Médio São Francisco, mas exportado para outras regiões da colônia (depois Império). Ressalte-se que o texto se refere implicitamente a alguns grupos sociais envolvidos no setor de transportes: os barqueiros, ou seja, os comerciantes e proprietários das barcas; os tropeiros, que viajavam com suas tropas nos caminhos do sertão; e os remeiros que se alugavam nas barcas. É possível que os carreiros com seus carros de bois já circulassem também na região.

Os primórdios da história de Salgado (atual Januária-MG) remontam ao século XVIII. Saint-Hilaire, que visitou o povoado, presta-nos informações sobre seu passado: "Antigamente cultivava-se 0 algodão nas vizinhanças de Salgado. O s comerciantes vinham buscá-lo fiado em tecido grosseiramente, e traziam em troca os objetos de que os habitantes necessitavam" (1975, p. 346). 
Revista de Antropologia, São Paulo, USP, 2003, v. 46 № 1.

É possível que entre os comerciantes citados pelo viajante francês estivessem os mercadores do sal em suas barcas. Mas o cronista constata a existência de outros produtos no porto de Salgado em 1819: "O açúcar e a aguardente são os principais gêneros que Salgado oferece em troca aos mercadores de sal, e é fácil compreender que vantagens deve fruir desse comércio uma localidade que, por sua lavoura, constitui no deserto uma espécie de oásis" (1975, p. 347).

Certamente, implementava-se a produção de açúcar e aguardente em grande escala visando o mercado. Nesse particular, é importante conhecer as informações legadas pelo monsenhor Pizarro: havia 38 engenhos em Brejo do Salgado. Situada a uma légua de distância do rio São Francisco, Salgado mantinha um porto fluvial onde se localizavam os armazéns de proprietários de engenhos (A raújo, 1822, p. 224-25). Vale ressaltar a existência de uma infra-estrutura de produção, armazenagem e transporte em Salgado, favorecendo o desenvolvimento do comércio.

Em 1867, a vila de Januária continuava sendo um importante entreposto do Médio São Francisco conforme relato do viajante inglês sir Richard Burton: "Encontramos no porto um certo número de canoas e oito barcas movidas com as varas habituais" (1977, p. 209). Em geral, as barcas traziam o sal da Bahia e levavam, na volta, a rapadura e a cachaça produzidas em Januária. Mas - cabe lembrar - outros produtos regionais também participavam do comércio ambulante sem perder de vista 0 transporte a frete: 0 "excedente" das culturas de vazante como o feijão e 0 milho; a farinha, alimento básico do barranqueiro, produzida nas casas de farinha de sítios e fazendas; couros e peles etc. Na segunda metade do século XIX, outro produto passou a ser explorado e comercializado: a borracha de maniçoba e mangabeira.

$O$ produto industrial inglês não estava presente apenas em Guaicuí, onde Burton o encontrou, mas em toda a região do Médio São Francis- 
co onde as barcas e ajoujos aportavam. Vejamos, a seguir, a descrição do porto de Januária em 1875, conforme James W. Wells:

No embarcadouro havia numerosas canoas, ajoujos e barcas que subiam ou desciam o rio trazendo cerâmica, mercadorias de Manchester, louça, sal e artigos menores de diversas naturezas, trazidos por terra até a parte baixa ou alta do rio, originárias do Rio de Janeiro ou da Bahia e muitas das quais seguirão de Januária até G oiás. (1995, p. 312)

Esta citação é exemplar, dentre outros motivos, por nos demonstrar claramente a existência de articulações inter-regionais. Ademais, vale ressaltar que os remeiros contribuíam indiretamente, com sua força de trabalho, para potenciar a acumulação de capital na Inglaterra. A louça a que se refere 0 autor são possivelmente os potes e quartinhas (moringas) que circulavam nas barcas. As louœiras da $C$ aatinguinha domiciliadas em Barra (BA) produziam a melhor louça da região.

Nas primeiras décadas do século XX, Januária continuava mantendo intercâmbio comencial com o estado de G oiás. Ali chegavam carreiros e guieiros em busca do seu principal produto de exportação: a rapadura. Os januarenses sabiam distinguir os carros goianos por serem maiores, com maior número de juntas de bois. ${ }^{14}$

Situada às margens do rio Corrente, afluente do São Francisco, Santa Maria da Vitória (BA) estava integrada à rede de relacooes sociais propiciada pelas barcas. Em 1882, D urval Vieira de Aguiar visitou a vila. Em seu relato, destaca-se a referência ao movimento das barcas em seu porto:

(Santa Maria da Vitória) possui um animado comércio, um excelente porto freqüentemente visitado por barcos de todas as procedências, e que fazem ali grandes negócios de compra, venda e permuta de gêneros; tem muitas e regulares casas de negócio. (Aguiar, 1979, p. 28) 
O comércio de Santa Maria era favorecido pela existência de produção agrícola local, de significativa importância em termos regionais. Plantava-se ali a cana-de-açúcar, destinada à fabricação de rapadura, cachaça e açúcar. Esses produtos competiam com a produção de Januária. Mas havia também o cultivo de feijão, mandioca, frutas etc.

Localizada à margem do rio G rande, afluente do Médio São Francisco, Campo Largo era uma das povoações que forneciam o sal da terra para localidades ribeirinhas e regiões adjacentes. Nos anos 1840, Ignácio Accioli Silva mencionou diversos povoados que recebiam o sal produzido em Campo Largo:

O (sal) das salinas porém de Campo Largo, além de igualmente seguir para algumas das partes supraditas, e para todas as que ora formam as comarcas do rio de São Francisco e Urubu, é ali comprado e conduzido para os antigamente arraiais da Conceição, Cavalcante, São Félix, Natividade, Chapada, Carmo, Almas, e outros lugares da província de G oiás, a troco de ouro, café, açúcar, solas, arroz pilado, tabaco, e mais alguns gêneros dali trazidos pelos que vêm anualmente comprá-lo. (1860, p. 30)

Certamente, carreiros e tropeiros operavam o transporte do sal para a província de $\mathrm{G}$ oiás trazendo de lá os produtos regionais. Mais uma comprovação das articulações inter-regionais.

Em 1882, D urval Vieira de Aguiar visitou Barreiras (BA), à margem do rio $\mathrm{G}$ rande, onde também se produzia cachaça, rapadura e açúcar. Mas em seu porto embarcava-se um outro produto cujo destino era Juazeiro (BA):

(Em Barreiras) (...) já se fazem avultadas transações de compra e venda de borracha da mangabeira, que é trazida pelos habitantes dos G erais de Minas e $G$ oiás, os quais aí suprem-se dos produtos naturais, especialmente do 
sal da terra que é artigo de muito negócio para exportar. Esse negócio da borracha já se vai engrandecendo de tal forma que já descem barcas com milhares de arrobas. (1979, p. 48)

Esta citação é também exemplar por caracterizar as ligações interregionais: o sal produzido em Campo Largo seguia de Barreiras para outras regiões enquanto a borracha de mangabeira vinha dos $\mathrm{G}$ erais para as margens do rio Grande. Seguia nas barcas até Juazeiro, onde era embarcada com destino a Salvador, o porto de sua exportação. E ste produto é um exemplo da escala de acumulação de capital. Havia uma atividade extrativa no campo: os barqueiros adquiriam o produto nas transações com comerciantes ribeirinhos; em Juazeiro, vendiam aos grossistas (atacadistas) que, por sua vez, o revendiam aos exportadores de produtos regionais em Salvador. Mas estes - a exemplo do coronel O ctacílio Nunes de Souza nas primeiras décadas do século XX - podiam contar com representantes em Juazeiro. Além da borracha de mangabeira, havia também a borracha de maniçoba - objeto de transações comerciais nas barcas. No século XX, Barreiras manteve a condição de núcleo de articulações inter-regionais:

O município tem muitas estradas para todas as direções, para cargueiros e carros. Por vezes, o coronel Wolney tem trazido seus carros de bois a esta cidade, carregados de mercadorias e do mesmo modo os tem levado à Vila de Duro no estado de G oiás.

(...) A travessia dos gerais seria diminuta e correria em G oiás, numa zona povoada, de lavoura e criação de muito gado, donde nos vem muita carne, gado, couros e borracha de mangabeira. (0 município de Barreiras e a Bacia do rio Grande, 1918, p. 480) 
Revista de Antropologia, São Paulo, USP, 2003, v. 46 № 1.

Nesse texto, vale ressaltar o papel social de carreiros e tropeiros na inter-relação do Médio São Francisco com Goiás. Ademais, é importante destacarmos um produto que foi objeto de intenso comércio nas barcas: 0 couro de boi, ou seja, o couro bovino secado ao sol. A carne a que se refere 0 autor é a prestigiosa carne seca goiana.

Só aparentemente Santa Rita (BA) estava isolada nos rincões do rio Preto, afluente do rio Grande. $\mathrm{O}$ engenheiro James Wells menciona diversos produtos da indústria européia nos "armazéns bem fornidos" daquela localidade (1995, p. 72). Na verdade, Santa Rita era um núcleo urbano integrado ao comércio do Médio São Francisco e de regiões adjacentes desde o século XIX. Vejamos, a seguir, algumas informações sobre sua economia nas primeiras décadas do século XX conforme Américo Correia da Silva:

Comércio e indústria - O comércio do município de Santa Rita é um dos mais prósperos da zona sanfranciscana. Contando com os abundantes recursos naturais das suas terras fertilíssimas; freqüentado por grande parte das populações do norte de G oiás e sul do Piauí, que nele vêm se abastecer dos gêneros de que têm necessidade, como se desfazer, vendendo, dos produtos das suas indústrias, esse município sempre possuiu um comércio ativo e em ótimas condições econômicas.

Exportando para a capital do Estado a borracha de maniçoba e de mangabeira, o couro de gado bovino, as peles de cabra, ovelha, veado, caetetu etc., a resina de jatobá e angico, as plumas de garça, a cera de carnaúba, a carne seca (do sertão); para as localidades do São Francisco e para todo o norte de G oiás e sul do Piauí as produções da sua lavoura, os cereais, 0 açúcar, a rapadura, a aguardente, a farinha de mandioca e outros mais, o município sempre gozou de grande prosperidade financeira. (1918, p. 596) 
As exportações para a capital do Estado eram implementadas por via fluvial. As barcas cumpriam uma importante função no transporte de mercadorias até Juazeiro. A partir daí até Salvador, o meio de transporte utilizado era o ferroviário. A Santa Rita chegavam as mercadorias transportadas pelas barcas; por via terrestre, seguiam em parte para os estados limítrofes com a Bahia.

Nos anos 1840, o cronista Ignácio Accioli Silva mencionou o sal da terra produzido em Sento Sé, o qual seguia para Juazeiro e localidades do Baixo São Francisco bem como para a Província do Piauí e para Jacobina (BA) (1860, p. 26-27).

Em 1879, o engenheiro Teodoro Sampaio resumiu, com acurada percepção, a importância histórica e estratégica de Juazeiro como pólo de articulações regionais e inter-regionais:

Situado na encruzilhada de duas grandes artérias de comunicação interior, isto é, a velha estrada histórica que da Bahia se encaminha para o Maranhão, através do Piauí, e a amplíssima estrada fluvial que desce de Minas e vai ao oceano através da Bahia, Pernambuco, Alagoas e Sergipe, o Juazeiro, fundado pelos fins do século XVII, se tornou logo um centro preferido das transações comerciais destas regiões, e cresceu e se constituiu o foco mais poderoso da civilização e da riqueza desta parte do Brasil, que se pode designar como a região média dentre os rios São Francisco e Tocantins. Por essa razão é aqui comumente denominada a praça entre os sertanejos, mantendo com o porto da Bahia um grosso trato, servido por cerca de 2 mil muares, que de ordinário fazem a grande travessia para o litoral em quinze dias de marcha regular. (2002, p. 103-04)

Vale ressaltar que, entre 1727 e 1731, se estabeleceu a primeira barca de passagem no lugar onde hoje se localizam as cidades gêmeas de Juazeiro (BA) e Petrolina (PE) (Informação G eral da Capitania de Per- 
nambuco, s./ n./ t., p. 297-98). A partir de então, Juazeiro cresceu em importância como núcleo de articulações inter-regionais. É importante destacar no texto acima o grande número de tropas de animais de carga que operavam o transporte de mercadorias entre Salvador e Juazeiro. Esta última cidade - vale lembrar - é o ponto final da navegação no Médio São Francisco para embarcações de grande tonelagem.

Em 1896, inaugurou-se a Estrada de Ferro do São Francisco estabelecendo a ligação entre as referidas cidades. Vinte anos depois, a importância da ferrovia ficou evidenciada neste texto de A nísio de Q ueiroz:

Todo o comércio do São Francisco e afluentes, compreendido nas zonas norte deste Estado e limítrofes de Minas, Goiás, Piauí e Pernambuco se abastecem por intermédio desta Estrada, sendo que somente de sal o consumo anual está calculado em 50.000 sacos de 68 kilos, que por si só produz uma renda superior a Rs. 100:000\$000. (1918, p. 641)

Em 1910 chegaram os trilhos da Estrada de Ferro Central do Brasil a Pirapora (MG) estabelecendo a ligação entre aquela cidade ribeirinha e Belo Horizonte e Rio de Janeiro. Pirapora é o porto inicial da navegação no Médio São Francisco para embarcações de maior capacidade de transporte.

A velha tecnologia das barcas integrou-se à moderna tecnologia das locomotivas estreitando os laços de integração da sociedade brasileira. Aquelas embarcações somente desapareceriam da paisagem são-franciscana nos anos 50 do século XX, sendo substituídas por embarcações mais modernas.

O s remeiros assumiram papel social relevante no sistema econômico regional, mas contribuíram também para a difusão de crenças e narrativas populares ao longo da ribeira: mitos, contos, lendas e milagres do Bom Jesus... Assim, foram atores importantes na formação do sistema 
mágico-religioso. Mas, nesse particular, ressaltamos o papel não menos importante das migrações.

\section{Traços do sistema mágico-religioso}

As crenças dos remeiros que tivemos a oportunidade de descrever no capítulo X do nosso livro (Neves, 1998, p. 241-67), com base em entrevistas e relatos, estão presentes também no conto regionalista. Nesse particular, vejamos um trecho do conto "Barca fantasma" de D. Martins de Oliveira, escritor nascido em Barra (BA):

No tempo da festa do padroeiro da Lapa, algumas pessoas que moram a montante da cidade e não podem ir levar ao santo o seu óbulo com as próprias mãos, confiam às águas mensageiras uma cuia ou cabaça, com uma vela acesa e contendo no bojo seu presente sagrado; no trajeto, se algum viajante ou canoeiro encontra aquilo, não lhe toca senão para desengastar dos garranchos ou galhos; quando chega ao seu destino, os remeiros, que já sabem do que se trata, apanham o que for e levam à gruta divina! (1931, p. 40)

Vale esclarecer que em 6 de agosto acontece a festa do Senhor Bom Jesus na cidade ribeirinha que tem o nome do santo: Bom Jesus da Lapa (BA). Lá se reúnem milhares de romeiros. É importante perceber no texto acima como diversas pessoas participavam do sistema mágio-religioso: 0 ribeirinho, que podia ser um roceiro, remetendo sua dádiva ao santo da Lapa; o canoeiro, que talvez fosse um pescador, facilitando a chegada da cabaça à gruta sagrada; e, por fim, o remeiro, que pessoalmente levava o óbulo ao Santuário. Esses tripulantes das barcas, assim como a maioria dos ribeirinhos, eram devotos fervorosos do Senhor 
Bom Jesus. Não se pode perder de vista que os contos de Martins de O liveira são ao mesmo tempo ficção e descrição de costumes regionais.

Era muito comum a remessa de dinheiro ao Bom Jesus conforme entrevistas. Segundo a crença dos ribeirinhos, o Cabodo d'Á gua - um duende fluvial - era o guardião das cabaças. Nesse particular, é importante ressaltar a interseção entre o catolicismo popular e a crença num dos seres míticos do rio.

Q uem ousasse violar a dádiva dos devotos, destinada ao santo, era exemplarmente punido conforme consta nas narrativas míticas. Vejamos esta crença nas palavras de Pai Tonho - personagem do conto "Barca fantasma" - , um velho barranqueiro que assim fala aos remeiros:

\begin{abstract}
A h!... meus amigo! D eus não demora a castigá os pecado dos home! Eles ia passano por aqui bem no dia do Padroêro, quando caiu um temporá em riba deles terrive e o machado de um raio decepou a barca em não sei quantos pedaço, e não ficou um home vivo pra contá a históra, por causo qui os qui o fogo do céu não queixou, minhocão comeu! (sic) (idem, p. 41)
\end{abstract}

Pai Tonho descreve o castigo dos céus que vitimou o barqueiro Severino e os remeiros de sua barca pelo fato de o referido patrão ter-se apossado do dinheiro das cabaças com a conivência dos trabalhadores. 0 padroeiro referido na citação é o Bom Jesus. No texto acima, há também uma referência ao Minhocão, outro ser mítico do rio, que os ribeirinhos descrevem como malfazejo. Responsável por naufrágios e queda de barreiras, o Minhocão destrói as casas e roças dos camponeses; e vira as canoas dos pescadores (Neves, 1998, p. 257). Catolicismo popular e crença nos mitos fluviais compõem um todo. $O$ utras crenças estão presentes na fala do Pai Tonho: "As barca, quando é benta e afunda assim, dá um gemido de cortá o coração. A de Severino, nem nada" (O liveira, 1931, p. 41). Alguns barranqueiros acreditavam que eram três os gemi- 
dos no momento do naufrágio, conforme mencionamos em nosso livro acima citado. Mas a trágica sina do personagem do conto não tem fim: Severino torna-se alma penada ou livuzia conforme a linguagem regional; ou, em outras palavras, assombração. Coletados em entrevistas de ribeirinhos, diversos casos revelam proibições relativamente à violação de objetos e crenças sagradas. Sua profanação implicava punições (Neves, 1998, p. 205).

Em seu conto "A araponga", Accioly Lopes menciona a crença dos trabalhadores nos seres míticos do rio: "Sucedem-se as cheias e vazantes e gerações de remeiros. De homens que pelo seu praticismo chegam a adivinhar segredos do rio; até mareta feita por Negro d'Água" (1978, p. 59). Para estabelecer uma relação amistosa com esse ser mítico, os remeiros e canoeiros atiravam ao rio pedaços de fumo de rolo (fumo em corda), conforme revelam as entrevistas. Essa dádiva era necessária para aplacar sua ira ou para ser merecedor de sua proteção nas atividades de pesca. Mas, no romance A dama do V elho Chico, Carlos Barbosa, autor residente em Ibotirama (BA), acrescenta outras informações sobre o mito através da fala de um personagem-remeiro:

Não era nego-d'água, a mocinha pudesse ficar sossegada. E se fosse, na barca tinha cachaça e muito fumo de rolo e o danado logo iria embora satisfeito, pois seria com prazer que os forneceriam ao moleque do rio. Talvez nem precisassem disso, pois a barcaça tinha uma figura de proa magnífica, feita por Francisco Guarany, de Santa Maria da Vitória. Um leão de barca grandioso o suficiente para assustar qualquer nego-d'água. (2002, p. 144-45)

No imaginário popular, as figuras de proa eram a garantia das barcas contra os duendes do rio. Esculpidas com bocarras escancaradas e olhos esbugalhados, serviam para afugentar o N ego d'Á gua. $\mathrm{O}$ senhor Francis- 
co Biquiba $\mathrm{G}$ uarany, mencionado pelo autor, não é personagem de ficção; foi o maior carranqueiro do rio São Francisco. $\mathrm{Na}$ atualidade, suas figuras de proa e carrancas são valiosas peças de museu, sendo consideradas preciosidades da arte popular brasileira.

O Cabodo d'Á gua e o N ego d'Á gua são personagens distintos de variantes de um mesmo mito. Compadre é o outro nome que lhes é atribuído. Esses seres míticos foram assim descritos em entrevistas: de cor preta ou melado, baixos, atarracados, de cabeca pelada. Em seu livro de memórias, Procuro o menino, D. Martins de Oliveira menciona a crença dos remeiros no Caboclo d'Á gua:

Na minha primeira noite tivemos de encostar o paquete num barranco para dormir em pleno deserto. Os dois camaradas (remeiros) não quiseram pernoitar dentro da embarcação. Temiam que o caboclo d'água, o deus do rio, viesse realizar alguma de suas tropelias, segurando-lhes as pernas e os arrastando para o fundo dos peraus. (1976, p. 218)

Este relato de O liveira encontra eco nas narrativas fantásticas de velhos remeiros e vapozeiros, nas quais figura o Compadre arrastando pescadores e roceiros para as profundezas do rio. $\mathrm{O}$ referido autor escreveu também o romance Caboclo d'Á gua.

Em seu romance Maleita, Lúcio Cardoso menciona também a presença do Compadre no discurso dos beiradeiros: "D e novo as lendas surgiam, o caboclo-d'água com as suas tropelias dentro do rio, as canoas viradas, os remeiros afogados nos redemoinhos imprevistos" (s./ d., p. 116). Em outros relatos, o Caboclo d'Água aparece como um ser benfazejo que protege a pesca e salva crianças do afogamento.

O utros seres míticos povoavam o imaginário dos remeiros e dos ribeirinhos em geral: a Mãe d'Água, o Cavalo d'Água, o Cachorrinho d'Água... Mas havia também os mitos da zona rural: o Romãozinho, 0 
Pé-de-G arrafa etc. A lenda da Cobra-de-A sas, contada e recontada pelos romeiros de Bom Jesus da Lapa (BA), é urbana, mas amplamente difundida na região. $O$ utros mitos presentes na tradição oral dos ribeirinhnos não eram específicos do Médio São Francisco: o Lobisomem, a Mula-Sem-Cabeça...

\section{Conclusão}

Sem desejar justificar a violência, podemos afirmar que a agressividade dos remeiros nas cidades ribeirinhas era proporcional à violência da discriminação social e do estigma que lhes eram impostos pela sociedade majoritária. Ainda assim, eles realizaram uma obra titânica integrando importantes regiões do Brasil do ponto de vista socioeconômico e cultural: o Sudeste, o Nordeste e o Centro-O este. Em dois séculos de trabalho, eles contribuíram para a formação e o desenvolvimento do mercado interno brasileiro.

\section{Notas}

1 Entrevista com o ex-remeiro João Francisco de Souza (João de Félix), nascido em 1913, em Pirapora (MG).

2 Entrevista com o ex-remeiro Antônio Xavier de Souza (Antônio Cachoeira), nascido em 1908, em Juazeiro (BA), (1980). Ver também Neves (1998, p. 165-90).

3 Entrevista com o ex-remeiro Benvindo Francisco de Souza, nascido em 1907, em Juazeiro (1980).

4 Idem.

5 Entrevista com dona Emília Neves (63 anos, de prendas domésticas), em Pirapora (1980). 
6 Entrevista com o comandante Francisco Leobas, da Cia. de Navegação do São Francisco (1980).

7 Entrevista com o comandante Francisco Leobas, já qualificado.

8 Depoimento com o sr. Joaquim Borges das Neves, comandante da FRANAVE (Companhia de Navegação do São Francisco), nascido em 1906, em Pirapora (MG), (1975).

9 Entrevista com o ex-remeiro Benvindo Francisco de Souza, nascido em 1907, em Juazeiro (1980).

10 D epoimento do senhor Joaquim Borges das Neves, já qualificado.

11 Entrevista com o senhor Wilson Castelo Branco (68 anos, comerciante), em Remanso (1980).

12 Entrevista com o sr. Benvindo Francisco de Souza (73 anos, ex-remeiro), em Juazeiro (BA) (1980).

13 Entrevista com o ex-remeiro Emídio Lopes da Silva, nascido em 1918, em Santa Maria da Vitória (BA) (1980).

14 Entrevista com dona O ctacília Andrade (90 anos), em Januária (MG) (1980).

\section{Referências bibliográficas}

ABC DO ANTÔNIO MONIZ

s./n./t.

AGUIAR, D. V.

1979 Descriộes práticas da província da Bahia. 2. ed., Rio de Janeiro/ Brasília, Cátedra/ MEC/ Instituto Nacional do Livro.

ARAÚJO, Monsenhor J. S. A. PIZARRO

1822

Memórias históricas do Rio de Janeiro e das Províncias A nex as à jurisdição do viœe rei do E stado do Brasil. Rio de Janeiro, Tipografia de Silva Porto, t. VIII.

ARINOS, A.

s./ d.

Pelo sertão. Rio de Janeiro, Tecnoprint, Coleção Prestígio. 
ÁVILA, A.

1967 Resíduos seiscentistas em Minas. Belo Horizonte, UFMG / Centro de Estudos Mineiros, v. 2.

BARBOSA, C.

2002

A dama do V elho Chio. Rio de Janeiro, Bom Texto.

BRAZ, P.

2002 Jandaia em tempo de seca. 2. ed., Montes Claros, Edibraz.

BURTON, R. F.

1977 V iagem de canoa de Sabará ao 0 ceano A tlântico. Belo Horizonte/ São Paulo, Itatiaia/ Edusp.

CARDOSO, L.

s./ d. Maleita. Rio de Janeiro, Tecnoprint.

CARVALHO, O. M.

19370 rio da unidade nacional: o São Francisco. São Paulo, Cia. Editora Nacional.

CASTRO, O. A.

s./ d. Porto Calendário. São Paulo, Símbolo.

GAUTHEROT, M.

1995 Bahia: rio São Francisco, Recôncavo e Salvador. Fotografias de Marcel G autherot. Rio de Janeiro, Nova Fronteira.

GEERTZ, C.

1978

A interpretação das culturas. Trad. Fanny Wrobel. Rio de Janeiro, Zahar.

GOFFMAN, I.

1982 E stigma - N otas sobre a manipulacão da identidade deteriorada. 4. ed., trad. Márcia Bandeira de Mello Leite Nunes. Rio de Janeiro, Zahar.

GONZAGA, O. M.

s./ d. M emória histórica de Paracatu. Paracatu-MG, edição do autor. 
HALFELD, H. G. F.

1860 A tlas e relatório concernentes à ex ploração do rio São Francisco, desde a Cachoeira de Pirapora até 0 oceano A tlântion. Rio de Janeiro, s./n.

INFORMAÇÃO GERAL DA CAPITANIA DE PERNAMBUCO

s./ n./ t. A nais da Biblioteca $\mathrm{N}$ acional, v. XXVIII.

LEAL, V. N.

1976 Coronelismo, enxada e voto. São Paulo, Alfa-Ômega.

LÉVI-STRAUSS, C.

1974 A obra de Marcel Mauss. In: MAUSS, Marcel. Sociologia e A ntropologia. Trad. de Lamberto Puccinelli. São Paulo: E.P.U./ UNESP; v. I; p. 1-36: Introdução.

LIMA SOBRINHO, B.

s./ d. D ocumentos H istóricos sobre a Comarca do São Francisoo. (Separata do v. IV e V de D ocumentos do Arquivo - Arquivo Público Estadual). Recife, Secretaria do Interior eJustiça/ Arquivo Público Estadual.

LINS, W.

1960 O Médio São Francisco: uma sociedade de pastores e guerreiros. Salvador, Livraria Progresso.

19650 reduto. São Paulo, Livraria Martins.

1967 Remanso da valentia. São Paulo, Livraria Martins.

1980 Militão sem remorso. Rio de Janeiro/ Brasília, Record/ MEC/ INL.

LOPES, A.

1978

Remeiros e romeiros do São Francisoo. Rio de Janeiro, Cátedra, p. 13-81.

MONTENEGRO, T. G. P.

1875 A província e a navegacãa do rio São Francisoo. Bahia, Imprensa Econômica.

MORIN, E.

1999 Por uma reforma do pensamento. In: PENA-VEGA, A. e NASCIMENTO, E. P. (O rgs.) 0 pensar complex 0: E dgar M orin e a crise da modernidade. Rio de Janeiro, Garamond. 
NANTES, Padre M.

1979 Relação de uma missão no rio São Francisco. São Paulo/ Brasília, Cia. Editora Nacional/ MEC/ INL.

NEVES, Z.

1998

$N$ avegantes da integração: os remeiros do rio São Francisco. Belo Horizonte, UFMG .

O MUNICÍPIO DE BARREIRAS E A BACIA DO RIO GRANDE

1918 A nais do 5ํㅡ Congresso Brasileiro de $\mathrm{G}$ eografia. Salvador, Instituto Histórico e Geográfico da Bahia/ Imprensa O ficial do Estado.

OLIVEIRA, D. M.

1931 No país das carnaúbas. Rio de Janeiro, edição particular, p. 13-31.

1976 Procuro o menino. Rio de Janeiro/ Brasília, Cátedra/ MEC/ INL.

PARDAL, P.

1974

Carrancas do São Francisoo. Rio de Janeiro, Serviço de Documentação Geral da Marinha.

PIERSON, D.

1972

0 homem no V ale do São Francisoo. Trad. Ruy Jungmann. Rio de Janeiro, Ministério do Interior/ Superintendência do Vale do São Francisco (Suvale), t. II.

QUEIROZ, A.

1918 Município de Juazeiro. A nais do $5^{0}$ Congresso Brasileiro de G eografia. Salvador: Instituto Histórico e G eográfico da Bahia/ Imprensa O ficial do Estado.

REG O, L. F. M.

$1936 \quad 0$ valle do S. Francison. Rio de Janeiro, Sociedade Capistrano de Abreu.

\section{SAINT-HILAIRE, A.}

1975a V iagem pelas províncias do Rio de Janeiro e Minas G erais. Trad. Vivaldi Moreira. Belo Horizonte/ São Paulo, Itatiaia/ Edusp.

1975b V iagem às nascentes do rio São Francisco. Trad. Regina Regis Junqueira. Belo Horizonte/ São Paulo, Itatiaia/ Edusp. 
SAMPAIO, T.

2002

0 rio São Francisoo e a Chapada D iamantina. São Paulo, Companhia das Letras.

SARAIVA, F. R. S.

2000

N ovissimo D icionário L atino-Português. Rio de Janeiro: Livraria Garnier.

SILVA, A. C.

1918

Memória histórico-geográfica do município de Santa Rita do Rio Preto. In: A nais do $5^{0}$ Congresso Brasileiro de $\mathrm{G}$ eografia. Salvador, Instituto Histórico e Geográfico da Bahia/ Imprensa O ficial do Estado.

SILVA, F. A.

1961 X iqueX ique e Marrecas: duas comunidades do Médio São Francisco. Rio de Janeiro, Comissão do Vale do São Francisco.

SILVA, I. A. C.

1860 Informação ou descrição topográfica e política do rio de São Francisco. Rio de Janeiro, Tipografia Francesa de Frederico Arfvedson.

SOUZA, J. A.

1996

Paix ões alegres. São Paulo, Globo.

SPIX, J. B. \& MARTIUS, C. S. P.

1981 V iagem pelo Brasil (1817-1820). Belo Horizonte/ São Paulo, Itatiaia/ Edusp, 2 v.

TRIGUEIROS, E.

1977 A língua e 0 foldore da Bacia do São Francisoo. Rio de Janeiro, MEC/ Funarte, Campanha de D efesa do Folclore.

UNGER, E. M.

19780 sertão do V elho Chio. Rio de Janeiro, Civilização Brasileira.

VICENTE, G.

1982 0s autos das barcas. 4. ed. Lisboa, Publicações Europa-América. 
WELLS, J. W.

1995

Três mil milhas através do Brasil. Trad. de Myriam Ávila. Belo Horizonte, Fundação João Pinheiros/ Centro de Estudos Históricos e Culturais, v. 2.

ZALUAR, A.

1985

A máquina e a revolta. São Paulo, Brasiliense.

ZARUR, J. 1946

A bacia do M édio São Francisco - uma análise regional. Rio de Janeiro, IBGE/

Conselho Nacional de G eografia.

\begin{abstract}
Along two centuries, the rowers have contributed for the formation and development of the regional economic system of the Sao Francisco River. D ue to their social importance, they have been mentioned by travelers and technicians in their reports on the region. However, their work, beliefs and social position may be known through fiction literature: they are part of the regional short stories and novels. Thus, these sources have been used in the continuity of our interpretation work started in the book $\mathrm{N}$ avegantes da integração: os remeiros do Rio São Francisco (Ed. UFMG) (Sailors of integration: the rowers of the Sao Francisco River - Publisher UFMG), in which we used, above all, the methodological resource of interviews. In the present article, reports and fiction literature are confronted with the information of the book mentioned above.
\end{abstract}

KEY-WORD S: rowers; boats; Sao Francisco River; regional economic system; ideology; stigma; work; short story; novel.

Recebido em dezembro de 2002. 